2019-06

\title{
Supply and demand in prehistory? Economics of Neolithic mining in northwest Europe
}

Schauer, P

http://hdl.handle.net/10026.1/13636

\begin{abstract}
10.1016/j.jaa.2019.03.001
Journal of Anthropological Archaeology

Elsevier
\end{abstract}

All content in PEARL is protected by copyright law. Author manuscripts are made available in accordance with publisher policies. Please cite only the published version using the details provided on the item record or document. In the absence of an open licence (e.g. Creative Commons), permissions for further reuse of content should be sought from the publisher or author. 


\section{Supply and demand in prehistory? Economics of Neolithic mining in northwest Europe}

\section{Peter Schauer ${ }^{1}$, Stephen Shennan ${ }^{1 *}$, Andrew Bevan ${ }^{1}$, Gordon Cook ${ }^{2}$, Kevan Edinborough ${ }^{1}$, Ralph Fyfe ${ }^{3}$, Tim Kerig ${ }^{4}$ and Mike Parker Pearson ${ }^{1}$}

*Corresponding author

1 Institute of Archaeology, University College London, 31-34 Gordon Square, London WC1H OPY, UK 2 Scottish Universities Environmental Research Centre, Rankine Avenue, Scottish Enterprise Technology Park, East Kilbride G75 OQF, UK

3 School of Geography, Earth and Environmental Sciences, University of Plymouth, Plymouth PL4 8AA, UK 4 Universität Leipzig, Historisches Seminar, Lehrstuhl für Ur- und Frühgeschichte, Ritterstr. 14, 04109 Leipzig, $\mathrm{DE}$

\section{Abstract}

The extent to which non-agricultural production in prehistory had cost-benefit motivations has long been a subject of discussion. This paper addresses the topic by looking at the evidence for Neolithic quarrying and mining in Britain and continental northwest Europe and asks whether changing production through time was influenced by changing demand. Radiocarbon dating of mine and quarry sites is used to define periods of use. These are then correlated with a likely first-order source of demand, the size of the regional populations around the mines, inferred from a radiocarbon-based population proxy. There are significant differences between the population and mine-date distributions. Analysis of pollen data using the REVEALS method to reconstruct changing regional land cover patterns shows that in Britain activity at the mines and quarries is strongly correlated with evidence for forest clearance by incoming Neolithic populations, suggesting that mine and quarry production were a response to the demand that this created. The evidence for such a correlation between mining and clearance in continental northwest Europe is much weaker. Here the start of large-scale mining may be a response to the arrival by long-distance exchange of high-quality prestige jade axes from a source in the Italian Alps.

Keywords: Neolithic, Britain, Northwest Europe, mining, quarrying, radiocarbon, population, land cover 


\section{Introduction}

What factors influenced non-subsistence production in prehistory? Did the scale of production activities and the costs these entailed respond to demand from some consumer population, whether for utilitarian or prestige/ritual goods, or was it impervious to such considerations? The mining and quarrying of stone to produce axes by the Neolithic societies of Europe provides an ideal example to address this question. Extraction sites are known from Portugal to Russia, and from Norway to Sicily (e.g. Weissgerber 1980; Lech 1995). The quantity of material produced at some of these sites was vast, and clearly in excess of local needs, as the wide distribution of the products confirms. The Rijckholt mines in the present-day Netherlands, for example, are estimated to have produced between 13 and 61 million kg of flint over a period of 600 years (Felder, Rademakers, and de Grooth $1998,75-77)$. The products from such sites were mostly axes, which have both survived in large numbers and have been catalogued in great detail (e.g. Zimmermann 1995; P. Pétrequin et al. 2012; Clough and Cummins 1979, 1988). These studies have shown that axes sometimes travelled far from their origin, for example Alpine jade axes found in Denmark and Scotland (Cassen et al. 2012).

The effort that went into producing such large quantities of material for distribution was substantial. Extraction sites were often in remote locations, far from settlements, as in the cases of Great Langdale in northern England (Bradley and Edmonds 1993) and Monte Viso in alpine Italy (Pétrequin and Pétrequin 2012). The process of extraction would often have been difficult and potentially hazardous, sometimes involving multi-chambered galleries at the bottom of deep shafts, as in some of the flint mines of Spiennes (e.g. Collet 2004). These activities had direct costs in terms of effort and risk, and represented a significant opportunity cost for the individuals and groups involved, as time spent quarrying and producing roughouts was time taken away from tasks related to subsistence and other activities.

Ethnographic studies of modern-day producers of stone axes have shown that cost-benefit considerations can be very relevant. In his study of New Guinea axe quarries, Burton (1989) argued that the demand created by a large nearby population was an essential requirement to justify the social 'expense' involved in a high level of axe production. He also showed that the production of traditional classes of valuables responded to similar economic forces to 
those that now govern the cultivation of cash crops; that is to say, the axe quarrymen were interested in exploiting the material that brought them the greatest return from those with whom they carried on exchange transactions. The Pétrequins' extensive studies of quarry exploitation in West Papua (1993) came to similar conclusions. People went to exploit the raw material when there was direct or indirect pressure from the first people in the exchange chain or the nearest recipients (Pétrequin and Pétrequin 1993, 366). Knapping activities involving a high risk of breakage were carried out at the extraction site to save wasted energy in carrying untested blocks to the village (ibid., 364). The Wano, who exploited the glaucophanite from the Yeleme massif, the hardest material in West Papua, were only about 2,000 in number but provided the material for axes and adzes for a population of over 130,000 of the Dani and related groups in the fertile agricultural valleys nearby (Pétrequin and Pétrequin 2017, 164). The Wano who exploited the raw material and produced the roughouts were specialist knappers; they did not carry out the timeconsuming activity of polishing themselves. Until 1958, when steel axes were introduced, they circulated as far as the limits of the massif to exchange roughouts for pigs, cowries, shell ornaments and other items. A quarter of their wives were given to them by farmers in the Yamo area on the border of the Wano who wanted to ensure their long-term access to the stone quarries, since this was the only way that exchanges could continue even in times of war (Pétrequin and Pétrequin 1993, 138). Some Wano specialised in bringing roughouts from quarries 'but these contacts were not sufficient to bring the large number of axes needed to pay compensations and it was constantly necessary to offer pigs, shells, feathers and tobacco to get the Wano to give up their roughouts of the hardest stone' (Pétrequin and Pétrequin 1993, 142; SS translation). When stone axes were superseded by steel the Wano were left isolated.

In this paper we gather together geo-referenced radiocarbon and other data on an unprecedented scale to ask whether the scale and intensity of mining and quarrying for axe production in Neolithic northwest Europe (c.5300-2000 BCE) was governed by a demand for the products that justified the effort involved. We start with the hypothesis that it was driven by the size of the regional population as the New Guinea examples would suggest, whether as a result of a fundamental role in social transactions or for more utilitarian reasons. If so, any changes through time in the size of the potential consumer population 
should be reflected in the scale of stone and flint quarrying and mining. If it turns out that the intensity of quarrying and mining does not relate to the size of the regional population then we need to consider alternative possibilities.

One such possibility is that the demand from the axe user population was not constant over time but varied according to changing needs. If the axes produced at mines and quarries had a significant utilitarian role then we would expect that variations in the scale of forest clearance would have had an impact on demand in addition to or distinct from that generated by the size of the regional population. This can be assessed by examining the evidence for human impact on the vegetation.

An alternative prediction is that large-scale axe production was stimulated by social factors. We therefore asked whether a relationship existed between the incidence of the large highquality jade axes imported from the alpine sources of Monte Viso and Monte Beigua that were indisputably of social/ritual importance (Pétrequin et al. 2012) and the episodes of mining and quarrying activity in our study area.

We focus mainly on Britain and northwest continental Europe, and to a lesser extent southern Scandinavia, because these regions contain a large number of important flint mines and stone quarries, and a great deal of fieldwork and scientific characterisation to identify raw material sources has taken place here over recent decades; they also have an exceptional record of other data sources that can be used to create reliable regional-scale proxies for population sizes and human impact on the vegetation (see e.g. Woodbridge et al. 2014) to address the supply-demand relationship. Finally, they offer contrasting situations. While farming arrived in Britain and southern Scandinavia 4000 BCE, it first appeared in continental northwest Europe 1000 years earlier.

\section{Materials and methods}

The axes and other products are not directly dateable, of course, since they are inorganic, and there are few reports of precisely dated contexts for axes (for Britain, see Whittle et al. 2011, table 14.140), since most of them are isolated finds. Moreover, while the sources of axes of non-siliceous stone can usually be identified, at least in broad terms, this is not 
generally the case with flint at present. Accordingly, any changes in mine and quarry exploitation must be identified by radiocarbon dating of activity at the sites themselves. We therefore reviewed all available literature on known flint and stone quarries and mines in most of Europe and compiled a list of all radiocarbon dates, starting with the Bochum catalogue (Weissgerber 1980; J. Lech 1995); we also collected new samples. This resulted in a dataset of 1194 dates, distributed amongst 118 mines in 20 countries. For Britain, continental northwest Europe and southern Scandinavia 425 dates are available.

Throughout this paper, these dates are referred to as "mine dates", regardless of the nature of the source.

Making inferences about the size of prehistoric populations has always been considered problematical by archaeologists, but the use of summed radiocarbon date probabilities (SPDs) from archaeological sites as a population proxy to address questions of demographic change in the archaeological record has become increasingly popular in recent years, following the development of a number of innovative techniques to address criticisms that have been made of this approach. These include methods to test for the statistical significance of departures from a given model of population change through time, taking into account the fluctuations in the calibration curve and the size of the available sample while down-weighting the effect of differential dating intensity at different sites (Shennan et al. 2013; Timpson et al. 2014; Edinborough et al. 2017); and also methods that test whether two date distributions are significantly different from one another, taking into account the same factors (Crema et al. 2016). In addition, studies have compared the patterns resulting from radiocarbon date distributions with those derived from other lines of evidence, including site counts and site settlement sizes (e.g. Palmisano et al. 2017), inferences from cemetery age-at-death distributions (Downey et al. 2014), evidence for land clearance (e.g. Lechterbeck et al. 2014), as well as multiple other proxies (e.g. Tallavaara et al. 2014) and shown strong correlations. In summary, there is strong reason to believe in the validity of SPD proxies so long as they are used appropriately.

These require the use of large numbers of dates to avoid sampling problems (cf. Williams 2012), and the development of the methods has gone hand-in-hand with the collection of large databases of radiocarbon dates. Building on previous work by the EUROEVOL project (Manning et al. 2016) and others, we have collected an updated list of georeferenced 
European radiocarbon dates from extensive literature reviews and available databases (see radiocarbon date references). This has been cleaned and checked for accuracy, especially with regard to location, site name and species of the dated material

Within each of the three regions, we defined a hinterland around each of those mines that has at least one radiocarbon date, on the assumption that this hinterland would contain the majority of the population creating the demand for that mine's products. The hinterland was defined as the area within a $100 \mathrm{~km}$ radius after tests showed that there was no difference in the population patterns between a hinterland size of $100 \mathrm{~km}$ and $200 \mathrm{~km}$; previous studies have also indicated that such distances are large enough to include most of a source's products in the great majority of cases (e.g. Bostyn 2015, de Grooth 2015). Where $100 \mathrm{~km}$ hinterlands overlapped between mines, dates were counted only once, producing the chains of merged circles shown in figure 1.

\begin{tabular}{|l|l|l|l|}
\hline & Great Britain & Northwest Europe & Southern Scandinavia \\
\hline mine sites & 14 & 31 & 3 \\
\hline mine dates & 181 & 184 & 60 \\
\hline $100 \mathrm{~km}$ hinterland dates & 5334 & 1930 & 1445 \\
\hline
\end{tabular}

Table 1: mine and hinterland dates

Within each hinterland we selected all dates within the range $6500 \mathrm{BC}$ to $1500 \mathrm{BC}$. These are referred to as "hinterland dates" and provide the proxy for demographic change in the hinterlands around the mines. This range is longer than the actual span of the Neolithic, especially in Britain and southern Scandinavia, but allows us to eliminate edge effects that might occur when using a shorter time period. Dates taken from environmental materials, such as peat, sediment and clay, were eliminated, as these are not clearly anthropogenic and could skew the demographic proxy. We also eliminated dates with an error of greater than 100 years, which had the effect of removing many older, less reliable dates and reduces the smearing effect created by wide date confidence intervals; however, this had the effect of removing the dates from one significant quarry, Plussulien in central Brittany (Le Roux 1999), which will be discussed below. This left a total of 8709 dates within the 
restricted study area around known mines and within the target date range. The mine and $100 \mathrm{~km}$ radius hinterland dates were used to create SPDs to stand as proxies for periods of mine activity and hinterland populations respectively (table 1). The individual date probability distributions from a given site were binned in 100 year intervals, which eliminates overlap between multiple close dates from the same site (Shennan et al. 2013). Binning preserves periods of high intensity, as indicated by multiple similar dates from multiple sites, while preventing sites with many dates from distorting the SPD. The SPDs were not normalised (see Bevan et al. 2017 for discussion) but were smoothed by 50 years for clarity.

The first step in the analysis was to evaluate whether there was any evidence of changes in the intensity of mining and quarrying over the course of the Neolithic in the regions concerned, or whether fluctuations in the mines SPD were simply a result of sampling variation and radiocarbon calibration effects. For this purpose the mine SPDs for each region were summed to produce an aggregate of all dated mine activity and the result was compared to a uniform null model that assumed there was no change in the intensity of mining once established. Thus, the null model was simulated 1000 times and the real distribution of mine dates was compared to it to see if it was significantly different (using the rcarbon package: Bevan and Crema 2017: modelTest() function, 'uncalsample'). In this test, dates from unique sites within the sample were not binned, as this would not give an adequate expression of the changing intensity of the use of mines or quarries through time, but to control for the possibility of heavily dated sites skewing the sample, we randomly chose repeated samples of five dates for all sites with five or more dates available; experiments showed that five dates represented a reasonable compromise between underand over-estimating the role of specific mines as a function of the investment in their radiocarbon dating (fig 3 shows the results for a single representative sample). The hinterland SPD, as the population proxy, was compared with a logistic null model that assumes that population growth resulting from the arrival of farming in a region would level off after an initial increase (fig 2).

To explore the relationship between the chronological distribution of mine activity and their hinterland populations in the three regions, an aggregate hinterland SPD was obtained by summing the individual hinterlands of each mine, but counting each unique date in the 
overlapping circles only once, as above. This was then compared with the aggregate mine activity SPD for the region. First, the correlation coefficient between them and its significance was calculated for each region (see results text), then the two SPDs were compared to see whether they were significantly different from one another. To carry out the comparison, we performed a permutation test (using the permtest() function in rcarbon: Bevan and Crema 2017). This repeatedly samples calibrated dates from the hinterland, with the size of the sample corresponding to the number of mine sites, to create a distribution of expected SPDs, which are then combined to form a 95\% mean confidence envelope. This is the distribution of mine dates through time that would be expected if the size of the regional population was the only factor that influenced it. The real SPD from the mines is then plotted against this, and areas of difference between the expected envelope and the observed mines are recorded (see fig 4). The total area of this difference is converted to a global $p$-value. Datasets that fit mostly within the observed envelope will have a high $p$ value that is not statistically significant, while those that deviate substantially will have a low $p$-value, and in these cases we can conclude that activity at the mine or quarry was influenced by factors additional to or other than the size of the regional population.

For the purpose of comparing mine activity with the evidence of human impacts on the vegetation the REVEALS (Regional Estimate of Vegetation from Large Sites) method was used (Sugita 2007). The REVEALS approach estimates percentage cover of plant taxa using a generalised version of the R-value model of Davis (1963), and requires pollen count data from large sites or networks of large and smaller sites (e.g. Fyfe et al., 2013), values for relative pollen production of taxa and fall speed of grains of different taxa (Broström et al. 2008). Additionally, the size of each basin from which pollen is obtained is required, and a taxon-specific dispersal and deposition function (Prentice 1985; Sugita 1994). We use here the relative pollen production values from Mazier et al. (2012). Pollen data were extracted from the European Pollen Database (Fyfe et al. 2009) and placed into 200 year contiguous time windows for use in the REVEALS analysis. Changing land cover through time was characterised by aggregating the results from individual pollen cores within a $125 \mathrm{~km}$ radius of a mine. The distance was selected because it enabled us to include significantly more pollen sites than a $100 \mathrm{~km}$ radius. The land cover values were correlated with the aggregate population and mine SPDs. Since it is possible that any correlation between changing land 
cover and mining activity could be influenced by an effect of population on both, the partial correlation between land cover and mining activity, controlling for population, was also calculated. REVEALS data were not available to us for southern Scandinavia so this analysis could not be carried out.

Finally, in order to explore the possibility that factors other than practical utilitarian ones played a role in stimulating demand for axes, we examined the relationship between the incidence of imported large high-quality, socially-important jade axes from the alpine sources of Monte Viso and Monte Beigua and the population patterns and episodes of mining activity. For this purpose, we used the database of the JADE project (Pétrequin et al. 2012) to identify all large jade axes within $200 \mathrm{~km}$ of our mining sites and the type to which they had been assigned. This typology can be used to estimate the frequency of axes by type at 100 year intervals, following the approximate chronology of the types in Pétrequin et al. $(2012,627)$. The Puymirol style, for example, is estimated to have begun around 4700 BCE and ended around 4100 BCE. To estimate the number of axes of this type which appeared at each 100 year interval in a given sample, we use an aoristic method, counting the number of axes and then divide by the number of intervals (see e.g. Crema 2011). By doing this for each type and summing the results, we can build up an estimated distribution of jade axes over time in each hinterland region. These distributions can then be tested for correlation with our mine and hinterland data, using the same Pearson's correlation coefficient used in the pollen tests above.

\section{Results}

\begin{tabular}{|l|l|l|l|}
\hline & Great Britain & Northwest Europe & Southern Scandinavia \\
\hline mines uniform test & $p=0.046$ & $p=0.001$ & $p=0.1019$ \\
\hline hinterland logistical test & $p=0.001$ & $p=0.001$ & $p=0.001$ \\
\hline
\end{tabular}

Table 2: model test results after 1000 simulations each. The first row of the table shows for each region the probability that the SPD of the mine dates corresponds to a flat uniform distribution implying that mining activity was constant over the period. The second row 
shows for each region the probability that the SPD of the hinterland dates corresponds to a logistic distribution; in other words to a population that rose with the arrival of farming and then levelled out.

The results (table 2 and fig 2) show that the hinterland samples of all three regions reject the logistical model of population growth at the 0.001 level. In other words, the size of the hinterland populations was not constant after the arrival of farming. In the case of both Britain and southern Scandinavia there is a very rapid increase in population with the arrival of farming c.4000 BCE, followed by a decline (cf. Bevan et al. 2017). In the case of northwest Europe there are several significant positive and negative deviations from the logistic model between the arrival of farming before 5000 BCE and the end of the Neolithic.

The test on the SPD of the mine dates (table 2, fig 3) allows us to reject the uniform model of no change in the intensity of mine and quarry exploitation for Britain and Northwest Europe but not for southern Scandinavia because of the small sample size of mines (only three). In fact, episodes of mining are remarkably concentrated. In Britain, the main feature is a positive departure from the uniform distribution c.4000-3600 BCE. In continental northwest Europe there is a strong negative deviation before $\sim 4300 \mathrm{BCE}$, followed by two strong positive deviations, from just after 4000 to $3700 \mathrm{BCE}$ and $3350-3100 \mathrm{BCE}$, with a final negative deviation at the end of the sequence. These results show that the intensity of mine exploitation was not uniform over time. We can therefore address the factors affecting it, starting with our hypothesis that it was driven by the size of the population creating a demand for axes.

For all three regions the correlation between mine exploitation and hinterland population is positive and significant (Britain $r=0.5247, p<0.0001$; NWE $r=0.2901, p<0.0001$, Scandinavia $r=0.5445, p<0.0001$ ), suggesting that the size of the hinterland population does play a role in accounting for changing mine exploitation. However, this does not tell the whole story. The results of the permutation tests comparing the mine SPDs and the hinterland SPDs are shown in table 3 and in figure 4. After running 1000 permutations of the test, we found a significant difference between the mine SPD and the hinterland mean confidence envelope in Northwest Europe and Britain but again not in Scandinavia. In other words, while there is some correlation between changes in the size of the regional 
population and changes in mining intensity, in the two regions with a reasonable sample size the patterns are significantly different from one another.

\begin{tabular}{|l|l|l|l|}
\hline & Great Britain & Northwest Europe & Southern Scandinavia \\
\hline permutation test & $p=0.025$ & $p=0.001$ & $p=0.2647$ \\
\hline
\end{tabular}

Table 3: permutation test results after 1000 simulations each. The test compares the actual SPD of mine dates for each region with the distribution of random samples of hinterland dates in which the size of the sample corresponds to the number of mine dates; the sampling is repeated 1000 times. The result shows the probability that the real mine date SPD corresponds to the hinterland population SPD.

While we should be cautious of over-interpreting specific areas of difference between the mine and hinterland SPDs, we can make some observations based on the location of the significant differences in each plot. In Britain farming arrives 4000 BCE (Collard et al. 2010, Whittle et al. 2011). Increased mine activity initially corresponds to the increase in population associated with the beginning of farming, then accelerates rapidly, leading the hinterland population increase, hence the departure from the $95 \%$ confidence envelope c.4000-3600 BCE (fig 4a). Mining activity then declined, before a short-lived possibly significant peak at around $3000 \mathrm{BC}$, after which there was further decline and final disappearance around $2000 \mathrm{BC}$.

In northwest Europe (figure 4b), hinterland population and mining SPDs are also significantly different from one another but the relationship between the distribution of mining activity and the hinterland population is quite different from Britain. While a small amount of mining activity is associated with the appearance of farming at $5000 \mathrm{BCE}$, until $4500 \mathrm{BCE}$ it is significantly below the scale predicted by the size of the hinterland population. It only begins to increase markedly in the late $5^{\text {th }}$ millennium BCE, reaching an initial peak, significantly higher than the population predicts, just after $4000 \mathrm{BCE}$, contemporary with that in Britain. Mining activity then declines along with the population around $3500 \mathrm{BCE}$, before rising again to another peak of activity in the centuries before $3000 \mathrm{BCE}$, again significantly higher than would be expected on the basis of the population, before decreasing steadily. 
The significant differences between the SPDs of mining activity and the surrounding regional population means that the need for axes of a population of a given size, whether for utilitarian or socially important purposes, is not sufficient by itself to account for the observed pattern. We therefore turn to the possibility that they were related to variations in the scale of forest clearance affecting the demand for axes for utilitarian purposes. For Britain the results of the analysis of the relationship between evidence of human impact on land cover inferred from the REVEALS pollen results and population and mining activity are shown in table 4 and figs $5 a$ and $6 a$.

\begin{tabular}{|c|c|c|c|c|c|c|}
\hline Taxa & $\begin{array}{l}\text { Hinterland } \\
\text { correlation }\end{array}$ & Hinterland $p$ & $\begin{array}{l}\text { Mine } \\
\text { correlation }\end{array}$ & Mine $p$ & $\begin{array}{l}\text { Mine Partial } \\
\text { Correlation }\end{array}$ & $\begin{array}{l}\text { Mine Part } \\
\mathrm{p}\end{array}$ \\
\hline Alnus & 0.6077 & $0.0002 * * *$ & 0.4379 & $0.0108 *$ & 0.124 & 0.4989 \\
\hline Artemisia & 0.432 & $0.0121 *$ & 0.5284 & $0.0016 * *$ & 0.3757 & $0.0341 *$ \\
\hline Betula & -0.3042 & 0.0852 & -0.4322 & $0.012 *$ & -0.3286 & 0.0663 \\
\hline Calluna vulgaris & -0.0327 & 0.8565 & -0.254 & 0.1537 & -0.2908 & 0.1064 \\
\hline Carpinus & -0.1776 & 0.3228 & -0.175 & 0.33 & -0.0884 & 0.6303 \\
\hline Cerealia- $t$ & 0.655 & $<0.0001 * * *$ & 0.3977 & $0.0219 *$ & 0.0187 & 0.9189 \\
\hline Corylus & -0.6088 & $0.0002 * * *$ & -0.7068 & $<0.0001 * * *$ & -0.5429 & $0.0013 * *$ \\
\hline Fagus & 0.6319 & $0.0001 * * *$ & 0.2277 & 0.2026 & -0.2316 & 0.2022 \\
\hline Filipendula & -0.1337 & 0.4583 & -0.2486 & 0.163 & -0.2121 & 0.2438 \\
\hline Fraxinus & 0.6124 & $0.0002 * * *$ & 0.6574 & $<0.0001 * * *$ & 0.4641 & $0.0075 * *$ \\
\hline Juniperus & -0.2945 & 0.0962 & -0.2773 & 0.1182 & -0.1343 & 0.4637 \\
\hline Picea & 0.2051 & 0.2522 & 0.2601 & 0.1438 & 0.176 & 0.3353 \\
\hline Pinus & -0.7365 & $<0.0001 * * *$ & -0.687 & $<0.0001 * * *$ & -0.4626 & $0.0077^{* *}$ \\
\hline Plantago lanceolata & 0.929 & $<0.0001 * * *$ & 0.482 & $0.0045 * *$ & -0.2202 & 0.226 \\
\hline Plantago media & 0.1768 & 0.3251 & -0.1178 & 0.5139 & -0.2793 & 0.1216 \\
\hline Poaceae & 0.4712 & $0.0056 * *$ & 0.7847 & $<0.0001 * * *$ & 0.7115 & $\begin{array}{l}<0.0001 \\
* * *\end{array}$ \\
\hline Quercus & 0.699 & $<0.0001 * * *$ & 0.5952 & $0.0003 * * *$ & 0.3168 & 0.0773 \\
\hline Rumex acetosa-t & -0.1418 & 0.4312 & -0.2203 & 0.218 & -0.171 & 0.3495 \\
\hline Salix & -0.0267 & 0.8826 & -0.2098 & 0.2412 & -0.2404 & 0.1851 \\
\hline Secale-t & 0.4061 & $0.019 *$ & 0.1816 & 0.3117 & -0.0784 & 0.6698 \\
\hline $\begin{array}{l}\text { Summed open } \\
\text { ground }\end{array}$ & 0.5304 & $0.0015 * *$ & 0.727 & $<0.0001 * * *$ & 0.605 & $0.0002 * * *$ \\
\hline Tilia & 0.2528 & 0.1557 & 0.4597 & $0.0071 * *$ & 0.3975 & $0.0243 *$ \\
\hline Ulmus & -0.5883 & $0.0003 * * *$ & -0.3417 & 0.0516 & 0.0079 & 0.9656 \\
\hline
\end{tabular}

Table 4: Correlations between REVEALS land cover values and the SPDs for population and mining activity for Britain, and the partial correlation between land cover values and the mining activity SPD controlling for population. Hinterland $=125 \mathrm{~km}$, hinterland $n=6269$, mine $n=181$. 
The results for Britain show significant correlations between increasing hinterland population and various anthropogenic indicators: elm (UImus) and hazel (Corylus) decline, and open ground species (Poaceae, Plantago lanceolata) and cereals (Cerealia-t) increase. There is also a significant correlation with an increase in ash (Fraxinus) (cf. Lechterbeck et al. 2014), a tree that is shade-intolerant and requires clearance to flourish; this may represent some compositional change within woodland following disturbance. The correlations for the mines are similar to the hinterlands, though weaker in three out of the five cases. The exceptions are Fraxinus, for which the correlation is slightly higher and Poaceae (grasses), for which the correlation with the mine SPD was almost double that for the hinterland population. Plantago lanceolata shows a similar pattern, though overall its correlation is higher with the hinterland population since its trend follows the later population increase when mining had declined. When partial correlations between land cover and mining activity are calculated, taking into account the possibility that both land cover and mining activity are to some degree influenced by the size of the hinterland population, Fraxinus and Poaceae still show significant correlations, and the latter actually has a higher correlation with mining activity than it does with population. Pinus and Corylus also still have significant negative correlations with mining activity when population is controlled, while Artemisia and Tilia have positive ones. Fig 5a shows aggregated open ground indicators (Plantago media, Artemisia, Calluna vulgaris, Cerealia-t, Filipendula, Plantago lanceolata, Poaceae, Rumex acetosa-t, Secale-t) and it can be seen that they lead both the increase and the subsequent decrease in the SPD population proxy and correlate better with the mining activity SPD, even when the effect of population is controlled (partial $r=0.605, p=0.0002$ ); fig 6a shows the pattern for Poaceae alone. The significant positive correlations for Alnus, Fagus, Quercus and Tilia and negative for Pinus with the population and/or mine activity proxies are likely to be spurious and to reflect ecological processes (e.g. competition, natural disturbance) rather than human activity.

\begin{tabular}{|l|l|l|l|l|l|l|}
\hline Taxa & $\begin{array}{l}\text { Hinterland } \\
\text { correlation }\end{array}$ & Hinterland p & $\begin{array}{l}\text { Mine } \\
\text { correlation }\end{array}$ & Mine p & $\begin{array}{l}\text { Mine Part } \\
\text { Correlation }\end{array}$ & $\begin{array}{l}\text { Mine Part } \\
\mathrm{p}\end{array}$ \\
\hline Abies & 0.5242 & $0.0017^{* *}$ & 0.5213 & $0.0019^{* *}$ & 0.3491 & 0.0502 \\
\hline Alnus & 0.7397 & $<0.0001^{* * *}$ & 0.3962 & $0.0225^{*}$ & 0.0391 & 0.8315 \\
\hline Artemisia & -0.5255 & $0.0017^{* *}$ & -0.3753 & $0.0314^{*}$ & -0.1497 & 0.4134 \\
\hline Betula & 0.1552 & 0.3884 & 0.3461 & $0.0485^{*}$ & 0.314 & 0.0801 \\
\hline Calluna vulgaris & -0.3281 & 0.0623 & -0.1907 & 0.2879 & -0.0307 & 0.8677 \\
\hline Carpinus & -0.2076 & 0.2464 & -0.1188 & 0.5101 & -0.0166 & 0.9281 \\
\hline
\end{tabular}




\begin{tabular}{|l|l|l|l|l|l|l|}
\hline Cerealia-t & 0.7346 & $<0.0001^{* * *}$ & 0.5042 & $0.0028^{* *}$ & 0.2276 & 0.2103 \\
\hline Corylus & -0.6712 & $<0.0001^{* * *}$ & -0.4158 & $0.0161^{*}$ & -0.1202 & 0.5123 \\
\hline Fagus & 0.3579 & $0.0409^{*}$ & -0.0264 & 0.884 & -0.2569 & 0.1557 \\
\hline Filipendula & 0.2094 & 0.2421 & -0.2508 & 0.1592 & -0.4224 & $0.016^{*}$ \\
\hline Fraxinus & 0.8552 & $<0.0001^{* * *}$ & 0.5634 & 0.0006 & 0.2942 & 0.1021 \\
& & & & & \\
\hline Juniperus & -0.2424 & 0.1741 & -0.1052 & 0.56 & 0.0205 & 0.9114 \\
\hline Picea & 0.3116 & 0.0776 & 0.3577 & $0.041^{*}$ & 0.2444 & 0.1777 \\
\hline Pinus & -0.6413 & $0.0001^{* * *}$ & -0.4181 & $0.0155^{*}$ & -0.1424 & 0.4368 \\
\hline $\begin{array}{l}\text { Plantago } \\
\text { lanceolata }\end{array}$ & 0.5649 & $0.0006^{* * *}$ & 0.0423 & 0.8151 & -0.341 & 0.0561 \\
\hline Poaceae & -0.1158 & 0.5212 & 0.166 & 0.3559 & 0.2618 & 0.1478 \\
\hline Quercus & -0.2075 & 0.2465 & -0.0028 & 0.9877 & 0.1208 & 0.5102 \\
\hline Rumex acetosa-t & 0.2504 & 0.1598 & 0.0733 & 0.6853 & -0.0636 & 0.7294 \\
\hline Salix & -0.0881 & 0.6258 & 0.0026 & 0.9885 & 0.0548 & 0.7659 \\
\hline Secale-t & 0.1357 & 0.4516 & -0.0844 & 0.6405 & -0.1788 & 0.3275 \\
\hline $\begin{array}{l}\text { summed open } \\
\text { ground }\end{array}$ & -0.1517 & 0.3993 & 0.1233 & 0.4944 & 0.2342 & 0.1969 \\
\hline Tilia & 0.7716 & $<0.0001 * * *$ & 0.4833 & $0.0044^{* *}$ & 0.1707 & 0.3502 \\
\hline Ulmus & -0.5145 & $0.0022^{* *}$ & -0.3885 & $0.0255^{*}$ & -0.1739 & 0.3411 \\
\hline
\end{tabular}

Table 5: Correlations between REVEALS land cover values and the SPDs for population and mining activity for NW Europe, and the partial correlation between land cover values and the mining activity SPD controlling for population. Hinterland $=125 \mathrm{~km}$, hinterland $n=2356$, mine $n=185$

The results of the correlations for continental northwest Europe are shown in table 5 and figure $5 \mathrm{~b}$ and are similar in some respects to those for Britain: significant negative correlations between the hinterland population proxy and Corylus and Ulmus; significant positive correlations with Cerealia-t, Plantago lanceolata and Fraxinus. However, there are also very marked differences. The highly significant correlation with Poaceae found in Britain is completely lacking; examination of fig $6 \mathrm{~b}$ shows that this may be because large areas of grass cover already existed in NW Europe prior to the arrival of farming. This is reflected in the very low and non-significant correlations between the combined open ground indicators and the mine activity and population proxies (table 5). Again, there are significant correlations with the REVEALS values for certain tree species - Abies, Alnus, Pinus and Tilia in this case - that are likely to be spurious. 
Thus, the results for Northwest Europe show some link between changing vegetation patterns and the increasing human populations associated with the local arrival of farming, but it is much less marked than in Britain. The patterning in the timing of large scale mining does not show a significant correlation with open-ground land cover and it begins centuries after the arrival of farming, coinciding with the Néolithique Moyen // period, while the second episode roughly corresponds to the Néolithique Récent.

\begin{tabular}{|l|l|l|}
\hline & Great Britain & Northwest Europe \\
\hline mines & $0.1309, \mathrm{p}=0.629$ & $0.7528, \mathrm{p}=0.0008 * * *$ \\
\hline $200 \mathrm{~km}$ hinterland & $-0.2252, \mathrm{p}=0.4017$ & $0.0861, \mathrm{p}=0.7511$ \\
\hline
\end{tabular}

Table 6: Correlations between the aoristic distribution of large jade axe frequency through time and the SPDs of mining (row 1 ) and hinterland dates (row 2) for Britain and northwest Europe.

If we turn to the relationship between mining activity and the incidence of imported large jade axes in the mine hinterlands, we find that in Britain, over the time range in which jade axes occur, there is no significant correlation between the number of jade axes and the population pattern, and no correlation between jade axes and mining activity (table 6 and fig 7a), because the main period of circulation of these axes preceded the arrival of farming in Britain. For northwest Europe, on the other hand (fig 7b), there is a highly significant correlation between the incidence of imported jade axes and flint mining activity $(r=0.7528$, $p=0.0008)$, though not with population.

\section{Discussion}

\section{Britain}


These results reveal much about the relationship between mining and quarrying activity and the demand for their products. The initial arrival of farming probably occurred slightly before 4000 BCE and by 3800 BCE it had spread across the whole of Britain (Whittle et al. 2011). The rapid expansion over this $\sim 200$ year period is reflected in the rise in pollen from open ground taxa resulting from clearance, on the one hand, and the simultaneous beginning and expansion of mining activity, which is at its peak at this time.

Population growth lags this activity and the population peaks 200 years later, by which time mining activity had already begun to decline, presumably because the main clearance phase was over. The evidence for mining activity continues to decrease, in step with the declining population, and also with decreasing cereal cultivation (Bevan et al. 2017), until an upturn at 3000 BCE for which the explanation is unclear.

Since we now know that the arrival of farming was a result of large-scale immigration by groups from the near continent (Brace et al. 2018, Olalde et al. 2018) we can conclude that the immigrant farmers immediately began mining and quarrying when they arrived in Britain, and established new sources and exchange links to distribute their products as the farming frontier rapidly expanded northwards (see Edinborough et al. under review for a discussion of this question). It appears that axes made of mined or quarried stone were in massive demand as a fundamental element of the clearance and colonisation process of the Neolithic settlers, who introduced the relevant technology, and that mining gradually declined once the colonisation phase was over. Given the date distribution of the majority of the relatively small number of jade axes from Britain and the aDNA evidence for largescale Early Neolithic colonisation, it is likely that they represent heirlooms brought with them by the new arrivals (Walker 2015). As far as the evidence goes, southern Scandinavia shows a very similar pattern to Britain, with flint-mining occurring at the very beginning of the Neolithic sequence, as population was rising. Here too we now know that the introduction of farming involved significant immigration (Mittnik et al. 2018).

\section{Northwest Europe}

The picture in northwest continental Europe is much more complex. There was no largescale mining for the first 1000 years after the initial arrival of farming here even though it 
was associated with a major population increase. Some small-scale flint mining activity took place and surface exploitation began at some of the main flint sources, such as Rijkholt, but the products were cores for a blade industry not flint axes (Zimmermann 1995), and therefore unsuitable for use in large-scale tree clearances; farming during this period did not require the large-scale local production of axes. This is despite the fact that hard stone adzes were extensively used in the ancestral Central European LBK Early Neolithic, occurring as far west as the Paris Basin, mostly derived from a source in the mountains of northern Bohemia (Přichystal 2015), and had utilitarian uses as well as social significance (Bentley et al. 2012). These had ceased to circulate to the west by the early $5^{\text {th }}$ millennium, which sees the introduction of the first large non-utilitarian Alpine jade axes.

It is apparent that there are two major mining episodes in continental northwest Europe; the first $\sim 4200-3800$ BCE and the second $\sim 3500-2900$ BCE, both far in excess of what would be predicted by the hinterland population size, though the first roughly correlates with the spatial expansion of farming settlement in the Chassean and Michelsberg phase (Vander Linden 2011). It also corresponds to the peak use of the metadolerite A source at Plussulien in central Brittany, where the majority of the production was apparently utilitarian (Le Roux $1999,208)$. The second mining episode in the late $4^{\text {th }}$ millennium BCE seems to occur at a time of population increase following a downturn but again is significantly greater than that predicted by the population pattern. There is no indication in our REVEALS data of a correlation with increasingly open ground cover, though David et al.'s (2015; see also Leroyer 2006) REVEALS study of the Paris Basin part of our study area does show a peak in Poaceae at this time.

The radiocarbon dates indicate that the northwest European colonisers of Britain whose mined flint and quarried stone axes were associated with the first farming clearance had only recently taken up large-scale flint mining and axe production themselves, in circumstances much less clearly linked with new clearance activity than in Britain. The stimulus for the demand that led to its onset may have been the arrival of the polished jade axes from the Alps discussed above, with their demonstrable high social value (e.g. Cassen et al. 2012). However, allowing for the lack of precision in dating the jade axes, there seems to be a lag of the order of 3-5 centuries between their initial appearance and the onset of mining, in contrast to the early start of small-scale production of non-utilitarian fibrolite 
axes in Brittany (Pailler 2016). Furthermore, some of the fibrolite axes imitate the form of jade axes while the flint axes do not (Giligny et al. 2012), though admittedly their shape is heavily constrained by the shape of the raw material nodules. Fig $7 \mathrm{~b}$ shows that the number of jade axes increases over the course of the 5th millennium BCE, peaking during the MN II period, $4200 \mathrm{BCE}$, contemporary with a population peak, and strongly overlapping with the mining activity date distribution, which peaks slightly later. Both decline rapidly from $\sim 3800$ $\mathrm{BCE}$, as does the population, with a significant decline below the prediction of the logistic model.

\section{Conclusion}

We have shown that the availability of new large-scale, spatially-referenced databases and associated analytical methods enables us to address long-standing questions concerning the factors affecting Neolithic quarry and mine production, in completely new ways.

For Britain we can reject the initial hypothesis that the changing intensity of mining and quarrying through time was simply a function of variations in demand arising from changing population sizes in the hinterlands of the sources. The strong correlation with the massive increase in grasses seen in the REVEALS results supports the hypothesis that it was a demand for utilitarian axes for woodland clearance that was a major stimulus for mining activity, and that this demand declined once this initial episode was over. This demand was apparently not fulfilled, or at least not completely, by using local surface stone sources, presumably because mined stone was of better quality for the production of working axes. These findings contradict the usual assumption that it was the needs of social transactions that governed their production and exchange.

In fact, although the farming colonisers of Britain came from continental northwest Europe, they seem to have placed less emphasis on the social role of mined and quarried axes obtained by exchange than their immediate ancestors, an interesting shift in values. For the latter, the onset of late $5^{\text {th }}$ millennium BCE mining seems to have been a response to a new demand for fine axes for social and ritual transactions stimulated by the circulation of the socially valorised alpine jade products. The rapid decline in evidence of mining activity also coincides with the decline in the occurrence of jade axes in the mine hinterland regions, no 
doubt exacerbated by the contemporary population decline. The renewed phase of mining in the late $4^{\text {th }}$ millennium BCE is associated with the recovery from this depression but is much more intense than predicted by it or by the currently available evidence for increased clearance activity. It thus remains to be understood.

Acknowledgements: This project was made possible by the award of a Standard Grant RPG2015-199 by Leverhulme Trust, to whom we are extremely grateful. Sue Colledge played an indispensable role in sorting out site names and coordinates for the radiocarbon dates. We are grateful to the editors of the journal and two anonymous reviewers for constructive comments that have greatly improved the paper.

\section{References}

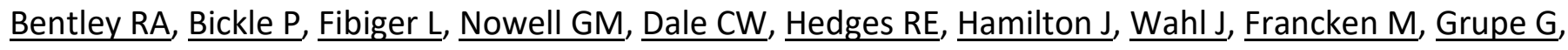

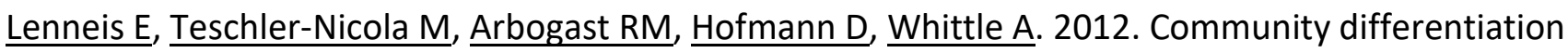
and kinship among Europe's first farmers. Proc Natl Acad Sci U SA. ;109(24):9326-30. doi: 10.1073/pnas.1113710109

Bevan, A. and E.R. Crema. 2017. rcarbon v1.1.3: Methods for Calibrating and Analysing Radiocarbon Dates. URL: https://CRAN.R-project.org/package=rcarbon

Bevan, A., S. Colledge, D. Fuller, R. Fyfe, S. Shennan and C. Stevens 2017. Holocene fluctuations in human population demonstrate repeated links to food production and climate. Proceedings of the National Academy of Sciences, 114, E10524-E10531.

Bostyn, F., 2015. Flint productions and distribution networks at the end of the 5th and beginning of the 4th millennia BC in northwestern France and western Belgium. In T. Kerig and S. Shennan (eds.), Connecting Networks: Characterising Contact by Measuring Lithic Exchange in the European Neolithic, pp. 74-82. Oxford: Archaeopress.

Brace, S., Y. Diekmann, T.J. Booth, Z. Faltyskova, N. Rohland, S. Mallick, M. Ferry, M. Michel, J. Oppenheimer, N. Broomandkhoshbacht, K. Stewardson, S. Walsh, M. Kayser, R. Schulting, O.E. 
Craig, A. Sheridan, M. Parker Pearson, C. Stringer, D. Reich, M.G. Thomas and I. Barnes. Population replacement in early Neolithic Britain. bioarXiv. DOI: http://dx.doi.org/10.1101/267443

Bradley, R., and M. Edmonds. 1993. Interpreting the Axe Trade :Production and Exchange in Neolithic Britain. Cambridge University Press.

Broström, A, Nielsen, AB, Gaillard, M-J, Hjelle, K, Mazier, F, Binney, H, Bunting ,M-J, Fyfe, RM, Meltsov, V, Poska, A, Räsänen, S, Soepboer, W, Stedingk, H, Suutari, H and Sugita, S. 2008. Pollen productivity estimates - the key to landscape reconstructions Vegetation History and Archaeobotany 17, 461-478

Burton, J.E. 1989 Repeng and the Salt-Makers: 'Ecological Trade' and Stone Axe Production in the Papua New Guinea Highlands. Man ns 24(2): 255-272

Cassen, S., Christine Boujot, Salvador Dominguez Bella, Mikaël Guiavarc'h, Christophe Le Pennec, Maria Pilar Prieto Martinez, Guirec Querré, Marie-Hélène Santrot, and Emmanuelle Vigier. 2012. 'Dépôts Bretons, Tumulus Carnacéens et Circulations À Longue Distance'. In Jade. Grandes Haches Alpines Du Néolithique Européen. Ve et IVe Millénaires Av. J.-C., 1280-1309. Besançon: Presses Universitaires de Franche-Comté.

Clough, T. H. McK, and W. A Cummins, eds. 1979. Stone Axe Studies: Archaeological, Petrological, Experimental, and Ethnographic. London: Council for British Archaeology.

Clough, T. H. McK., \& W. A. Cummins (eds.) 1988. Stone axe studies 2: the petrology of prehistoric stone implements from the British Isles. London: Council for British Archaeology [Research Report 67]

Collard, M., Edinborough, K., Thomas, M. G., Shennan, S. J. 2010. Radiocarbon evidence indicates that migrants introduced farming to Britain. Journal of Archaeological Science 37 (2010): 866-870.

Collet, H. 2004: Les Mines Néolithique de Spiennes: état des Connaissances et Perspectives de Recherche. In The Neolithic in the Near East and Europe. Acts of the XIVth UISPP Congress, University of Liège, Belgium, 2-8 September 2001. Oxford, BAR Int. Ser. 1303, 129-33.

Crema, E.R., 2012. Modelling temporal uncertainty in archaeological analysis. Journal of Archaeological Method and Theory 19(3), 440-461.

Crema, E.R., Habu, J., Kobayashi, K. and Madella, M., 2016. Summed Probability Distribution of 14 C Dates Suggests Regional Divergences in the Population Dynamics of the Jomon Period in Eastern Japan. PloS ONE 11(4), p.e0154809

David, R., Leroyer, C., and Mazier, F. 2015. Les modélisations du couvert végétal en palynologie. Pour une meilleure restitution des paléoenvironnements végétaux. Les Nouvelles d'Archéologie 138, 44-49.

Davis, M.B., 1963. On the theory of pollen analysis. American Journal of Science 261, 897-912 
De Grooth, M., 2015. The 'Rijkholt' connection: Neolithic extraction and circulation of Lanaye flints. In T. Kerig and S. Shennan (eds.), Connecting Networks: Characterising Contact by Measuring Lithic Exchange in the European Neolithic, pp. 24-41. Oxford: Archaeopress.

Downey SS, Bocaege E, Kerig T, Edinborough K, Shennan S. 2014. The Neolithic Demographic Transition in Europe: Correlation with Juvenility Index Supports Interpretation of the Summed Calibrated Radiocarbon Date Probability Distribution (SCDPD) as a Valid Demographic Proxy. PLoS ONE 9(8): e105730. doi:10.1371/journal.pone.0105730

Edinborough, K., Porčić, M., Martindale, A., Brown, T.J., Supernant, K., Ames, K.M. 2017. Radiocarbon test for demographic events in written and oral history. Proceedings of the National Academy of Sciences of the United States of America, 114, 12436-12441

Edinborough, K., S.Shennan, A. Teather, J. Baczkowski, A. Bevan, R. Bradley, G. Cook, T. Kerig, M. Parker Pearson, A. Pope, P. Schauer, under review. New radiocarbon dates show Early Neolithic date of flint-mining and stone quarrying in Britain.

Felder, P. J. (Sjeuf), P. Cor M. Rademakers, and Marjorie E. Th. de Grooth, eds. 1998. Excavations of Prehistoric Flint Mines at Rijckholt- St. Geertruid (Limburg, The Netherlands). Archäologische Berichte, Bd. 12. Bonn: Habelt.

Fyfe, RM, de Beaulieu, J-L, Binney, H, Bradshaw, RHW, Brewer, S, Le Flao, A, Finsinger, W, Gaillard, M-J, Giesecke, T, Gil-Romera, G, Grimm, EC, Huntley, B, Kunes, P, Kuhl, N, Leydet, M, Lotter, AF, Tarasov, PE and Tonkov, S (2009) The European Pollen Database: past efforts and current activities. Vegetation History and Archaeobotany 18, 417-424

Fyfe RM, Twiddle C, Sugita S, Gaillard M-J, Barratt P, Caseldine CJ, Dodson J, Edwards KJ, Farrell M, Froyd C, Grant MJ, Huckerby E, Innes JB, Shaw H and Waller M. 2013. The Holocene vegetation cover of Britain and Ireland: overcoming problems of scale and discerning patterns of openness. Quaternary Science Reviews 73, 132-148

Giligny, F., F. Bostyn and N. Le Maux 2012. Production et importation des haches polies dans le Bassin parisien : typologie, chronologie et influences. In Pétrequin, S. Cassen, M. Errera et al. (eds), JADE: Grandes haches alpines du Néolithique européen. Ve et IVe millénaires av. J.-C., pp. 1136-1167. Besançon: Presses Universitaires de Franche-Comté.

Klassen, L., Cassen, S., and Pétrequin, P., 2012. Alpine axes and early metallurgy. In P. Pétrequin, S. Cassen, M. Errera et al. (eds), JADE: Grandes haches alpines du Néolithique européen. Ve et IVe millénaires av. J.-C., pp. 1280-1309. Besançon: Presses Universitaires de Franche-Comté.

Lech, J. 1995. Flint Mining. Special Theme Issue. Archaeologia Polonia 33. 
Lechterbeck, Jutta, Kevan Edinborough, Tim Kerig, Ralph Fyfe, Neil Roberts, and Stephen Shennan. 2014. 'Is Neolithic Land Use Correlated with Demography? An Evaluation of Pollen-Derived Land Cover and Radiocarbon-Inferred Demographic Change from Central Europe'. The Holocene, 24, 1297-1307

Le Roux, C.T., 1999. L'outillage de pierre polie en métadolérite du type A. Les ateliers de Plussulien (Côtesd'Armor: production et diffusion au Néolithique dans la France de l'ouest et au-delà. Rennes : Université de Rennes I.

Leroyer, C. 2006. L'impact des groupes néolithiques du Bassin parisien sur le milieu végétal : évolution et approche territoriale d'après les données polliniques. In P. Duhamel (ed.), Impacts interculturels au Néolithique moyen, p. 131-149 (25e suppl. à la Revue Archéologique de l'Est.).

Manning, K., A. Timpson, S. Colledge, E. Crema, K. Edinborough, T. Kerig, and S. Shennan. 2014. 'The Chronology of Culture: A Comparative Assessment of European Neolithic Dating Approaches'. Antiquity 88 (342):1065-1080. https://doi.org/10.1017/S0003598X00115327.

Mazier, F., Gaillard, M.J., Kune_s, P., Sugita, S., Trondman, A.K., Broström, A., 2012. Testing the effect of site selection and parameter setting on REVEALS-model estimates of plant abundance using the Czech Quaternary Palynological Database. Review of Palaeobotany and Palynology 187, 38-49.

Mittnik, A., Chuan-Chao Wang, Saskia Pfrengle, Mantas Daubaras, Gunita Zariṇa, Fredrik Hallgren, Raili Allmäe, Valery Khartanovich, Vyacheslav Moiseyev, Mari Tõrv, Anja Furtwängler, Aida Andrades Valtueña, Michal Feldman, Christos Economou, Markku Oinonen, Andrejs Vasks, Elena Balanovska, David Reich, Rimantas Jankauskas, Wolfgang Haak, Stephan Schiffels \& Johannes Krause 2018. The genetic prehistory of the Baltic Sea region. Nature Communications 9, Article number: 442

Olalde I, Brace S, Allentoft ME et al. 2018. The Beaker Phenomenon and The Genomic Transformation of Northwest Europe. Nature 555: 190-196.

Pailler, Y., 2016. La fibrolite, un matériau pour façonner des haches, mais encore ? Le travail de la fibrolite au Néolithique dans l'Ouest de la France. In de Labriffe, P.A., and Thirault, E., (eds.), Produire des Haches au Néolithique : de la Matière Première à l'Abandon, 121-136. Paris : Société préhistorique française.

Palmisano, A., A. Bevan and S. Shennan 2017. Comparing archaeological proxies for long-term population patterns: An example from central Italy. Journal of Archaeological Science 87: 59-72.

Pétrequin, A.M., and P. Pétrequin. 1993. Ecologie D’un Outil : La Hache de Pierre En Irian Jaya (Indonésie). CNRS éd. Paris.

Pétrequin, A.M., and P. Pétrequin 2017. Modélisation ethnoarchéologique en Nouvelle-Guinée : techniques, modes de production et circulation des producteurs. In Pétrequin, P., E. Gauthier, and 
A.M.Pétrequin (eds.). Jade. Objets-Signes et Interprétations Sociales Des Jades Alpins Dans l'Europe Néolithique. JADE volume 3, pp 159-182. Presses universitaires de Franche-Comté et Centre de recherche archéologique de la vallée de l'Ain.

Pétrequin, P., S. Cassen, M. Errera, L. Klassen, J. A. Sheridan, and A.-M. Pétrequin. 2012. Jade. Grandes Haches Alpines Du Néolithique Européen. Ve et IVe Millénaires Av. J.-C. Besançon: Presses Universitaires de Franche-Comté.

Pétrequin, P., and Pétrequin, A.M., 2012. Chronologie et organisation de la production dans le massif du Monte Viso. Pétrequin, P., S. Cassen, M. Errera, L. Klassen, J. A. Sheridan, and A.-M. Pétrequin. 2012. Jade. Grandes Haches Alpines Du Néolithique Européen. Ve et IVe Millénaires Av. J.-C., pp. 214-257. Besançon: Presses Universitaires de Franche-Comté.

Pétrequin, P., Sheridan, J.A., Gauthier, E., Cassen, S., Errera, M., Klassen, L., 2015. Projet JADE 2.'Objectsigns' and social interpretations of Alpine jade axeheads in the European Neolithic: theory and methodology, in: Kerig, T., Shennan, S. (Eds.), Characterising Contact by Measuring Lithic Exchange in the European Neolithic. Archaeopress, Oxford, pp. 83-102

Prentice, I.C., 1985. Pollen representation, source area, and basin size: toward a unified theory of pollen analysis. Quaternary Research 23, 76-86.

Přichystal, A. 2015. Key raw material for Neolithic shoe-last celts and axes in Central Europe: their sources and distribution. In Kerig, T., Shennan, S. (eds.), Characterising Contact by Measuring Lithic Exchange in the European Neolithic, pp. 1-7. Archaeopress, Oxford,

Shennan, S., S.S. Downey, A. Timpson, K. Edinborough, S. Colledge, T. Kerig, K. Manning, and M.G. Thomas. 2013. 'Regional Population Collapse Followed Initial Agriculture Booms in Mid-Holocene Europe'. Nature Communications 4 :2486. https://doi.org/10.1038/ncomms3486.

Sugita, S., 1994. Pollen representation of vegetation in Quaternary sediments: theory and method in patchy vegetation. Journal of Ecology 82, 881e897

Tallavaara, M., P. Pesonen, M. Oinonen \& H. Seppä 2014. The mere possibility of biases does not invalidate archaeological population proxies - response to Teemu Mökönen. Fennoscandia archaeologica XXXI, 135-140.

Timpson, Adrian, Sue Colledge, Enrico Crema, Kevan Edinborough, Tim Kerig, Katie Manning, Mark G. Thomas, and Stephen Shennan. 2014. 'Reconstructing Regional Population Fluctuations in the European Neolithic Using Radiocarbon Dates: A New Case-Study Using an Improved Method'. Journal of Archaeological Science 52 (December):549-57. https://doi.org/10.1016/i.jas.2014.08.011. 
Vander Linden, M. 2011. To tame a land: archaeological cultures and the spread of the Neolithic in western Europe. In B.W. Roberts and M. Vander Linden (eds.), Investigating Archaeological Cultures, pp. 289-319. Springer.

Walker, K., 2015. Axe heads and identity: an investigation into the roles of imported axe-heads in identity formation in Neolithic Britain. Unpublished PhD thesis, University of Southampton Research Repository.

Weissgerber, G. 1980. 5000 Jahre Feuersteinbergbau. Bochum: Deutsches Bergbau Museum.

Whittle, A., Healy, F.M., Bayliss, A., 2011. Gathering time: dating the early Neolithic enclosures of southern Britain and Ireland. Oxford: Oxbow Books.

Williams, A.N. 2012. The use of summed radiocarbon probability distributions in archaeology: a review of methods. Journal of Archaeological Science 39, 578-589.

Woodbridge, J., Fyfe, R.M., Roberts, N., Downey, S., Edinborough, K., Shennan, S. 2014. The impact of the Neolithic agricultural transition in Britain: a comparison of pollen-based land-cover and archaeological $14 \mathrm{C}$ dateinferred population change, Journal of Archaeological Science. 51, 216-224

Zimmermann, A. 1995. Austauschsysteme von Silexartefakten in Der Bandkeramik Mitteleuropas. Bonn: Habelt. 


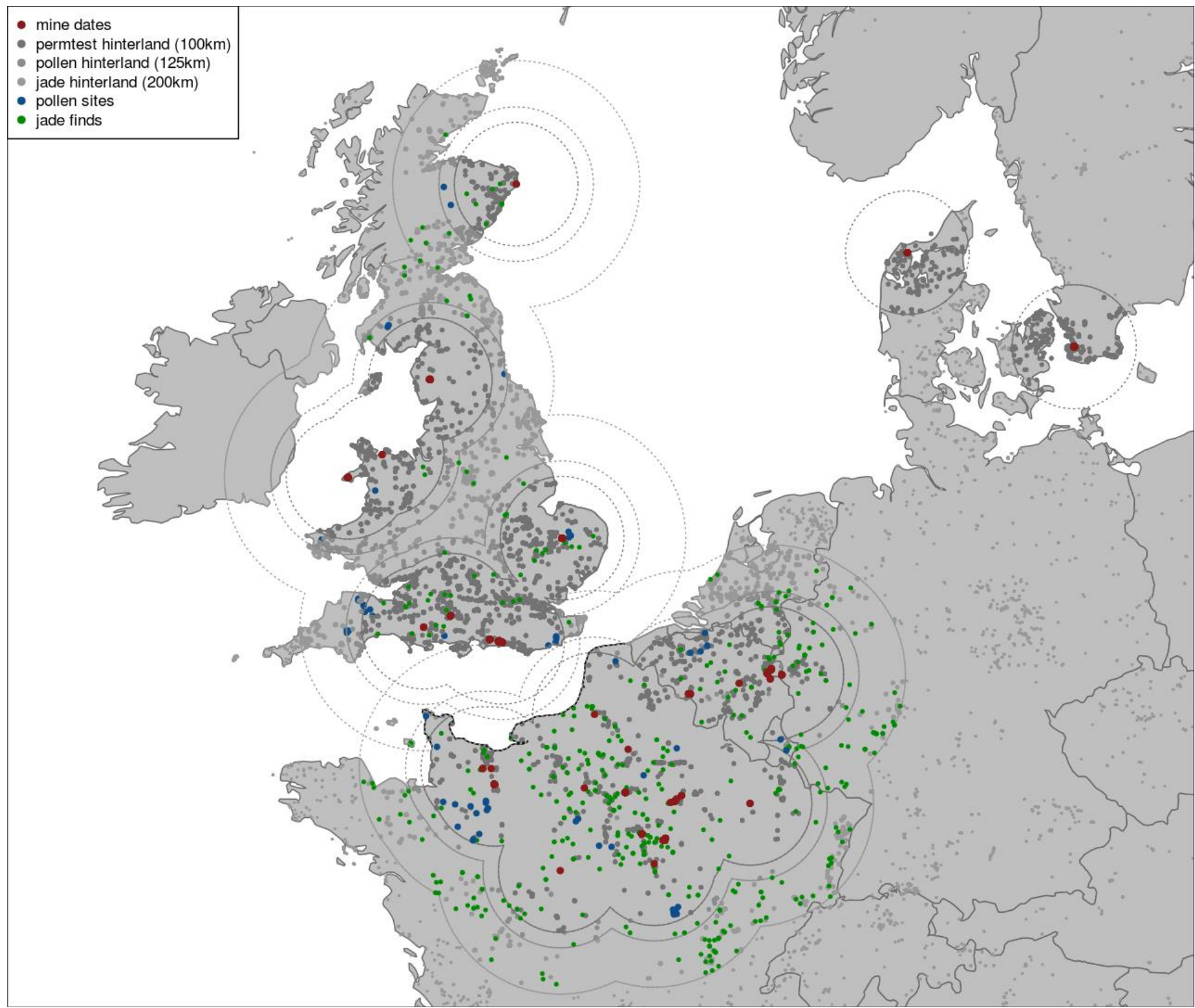

Fig 1 Hinterland circles showing mines, dates and pollen core locations a) Britain b) NW Europe c) South Scandinavia 


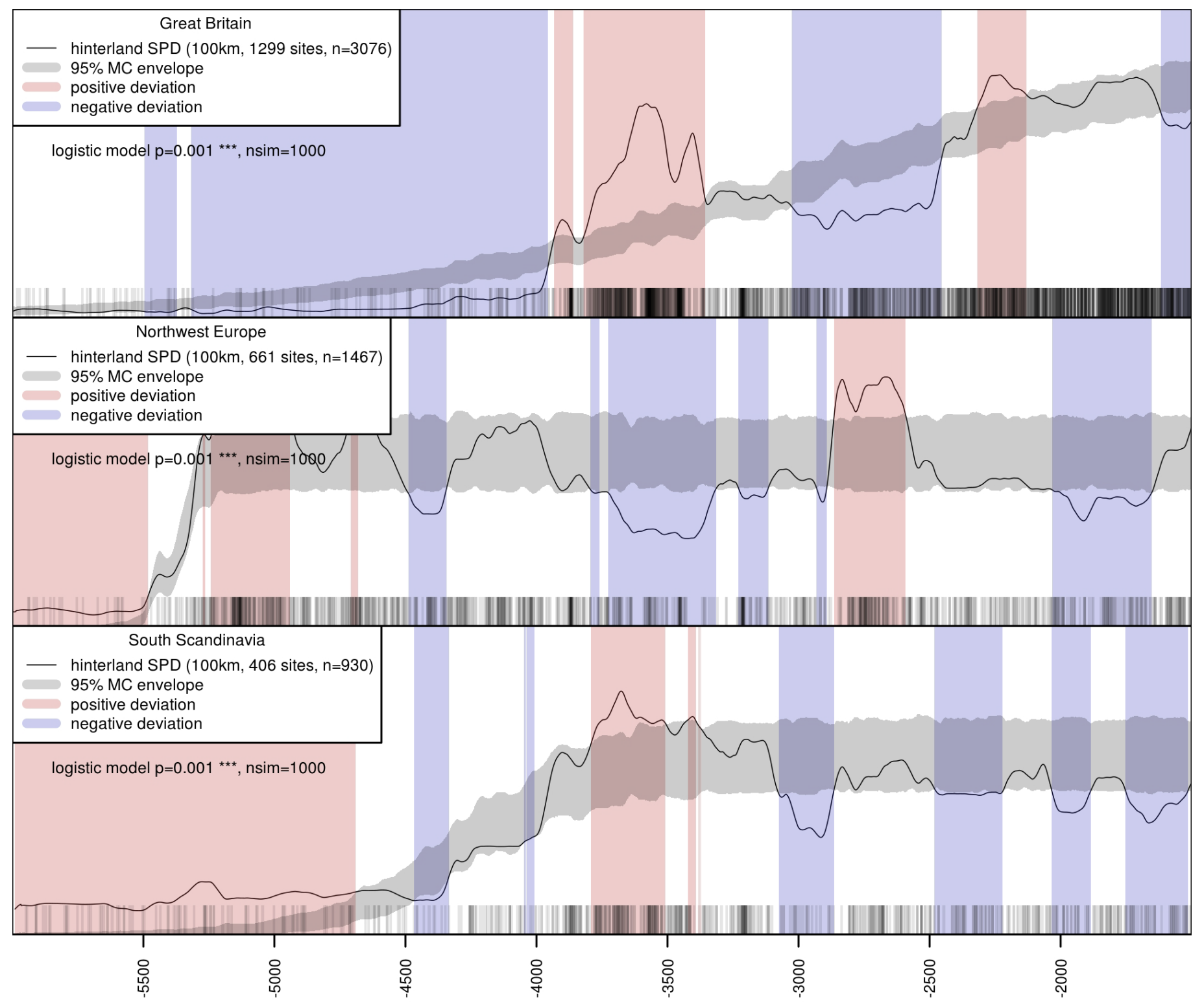

Fig 2 Logistic hinterland test a) Britain b) NW Europe c) South Scandinavia. For each region the figures shows the actual SPD of hinterland dates against the $95 \%$ confidence envelope generated by the null model of a logistic distribution implying that population rose with the arrival of farming and then levelled out, replicated 1000 times taking into account sample size and the calibration curve. 


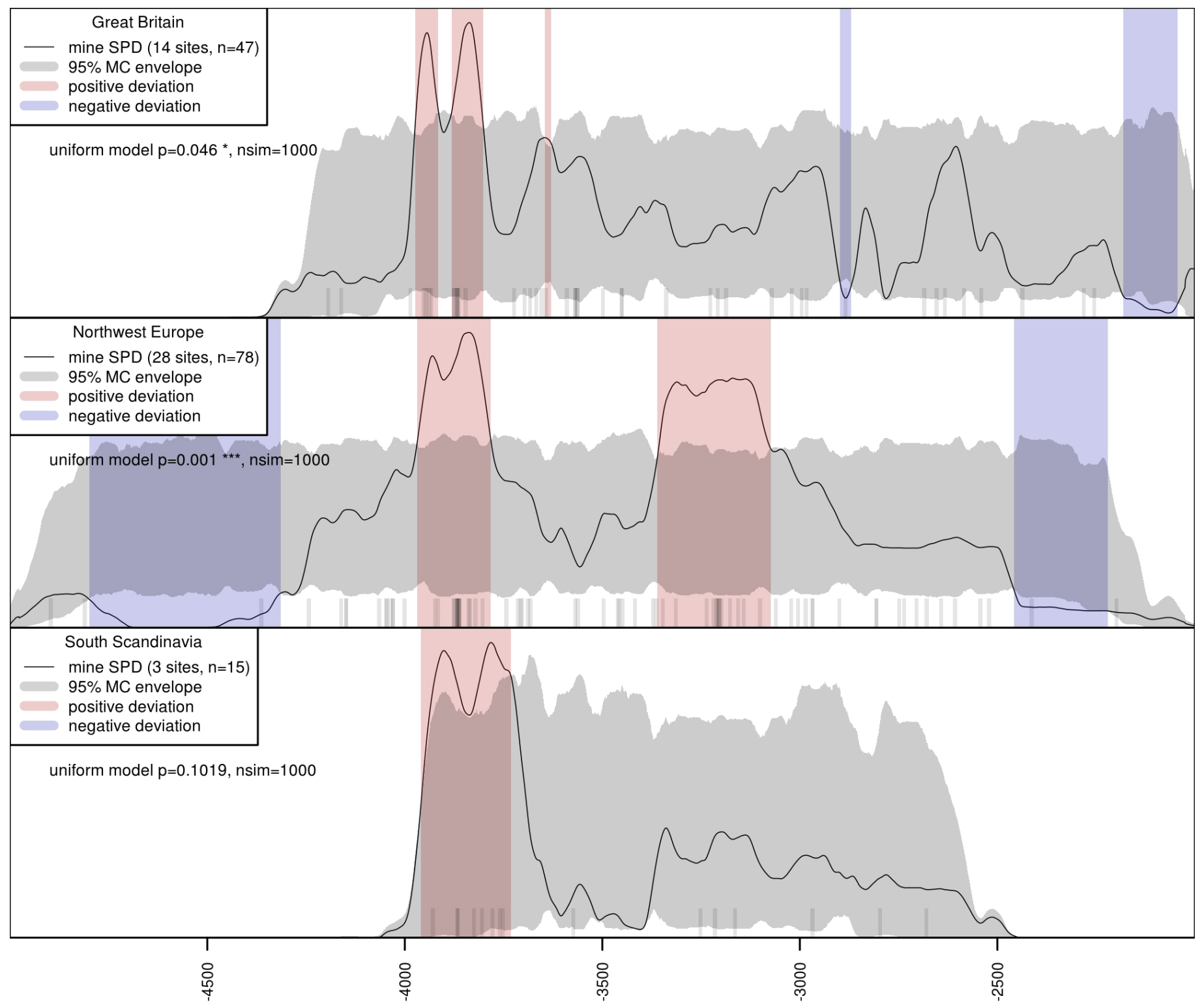

Fig 3 Uniform test on mine SPDs a) Britain b) NW Europe c) South Scandinavia. For each region the figures shows the actual SPD of mine dates against the $95 \%$ confidence envelope generated by the null model of a uniform distribution implying that mining activity was constant over the period, replicated 1000 times, taking into account sample size and the calibration curve. 


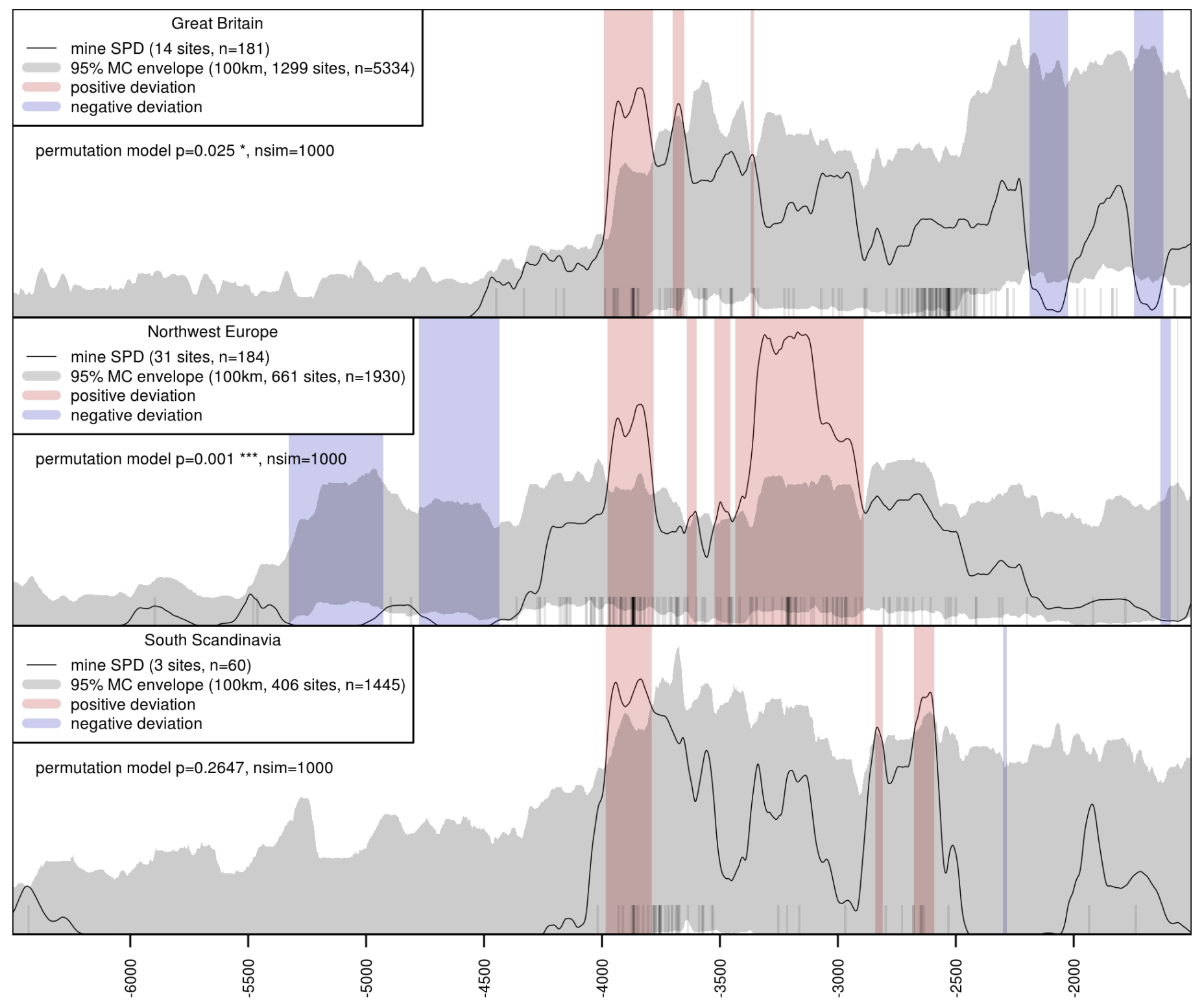

Fig 4 Permutation test on mines and hinterlands a) Britain b) NW Europe c) South Scandinavia. For each region the figure shows the actual SPD of mine dates for each region against the $95 \%$ confidence envelope generated under the assumption that it corresponds to the hinterland SPD distribution, by taking 1000 random samples of hinterland dates in which the size of the sample corresponds to the number of mine dates, taking into account the calibration curve. The dashes along the horizontal chronological axis represent the medians of the individual dates. 


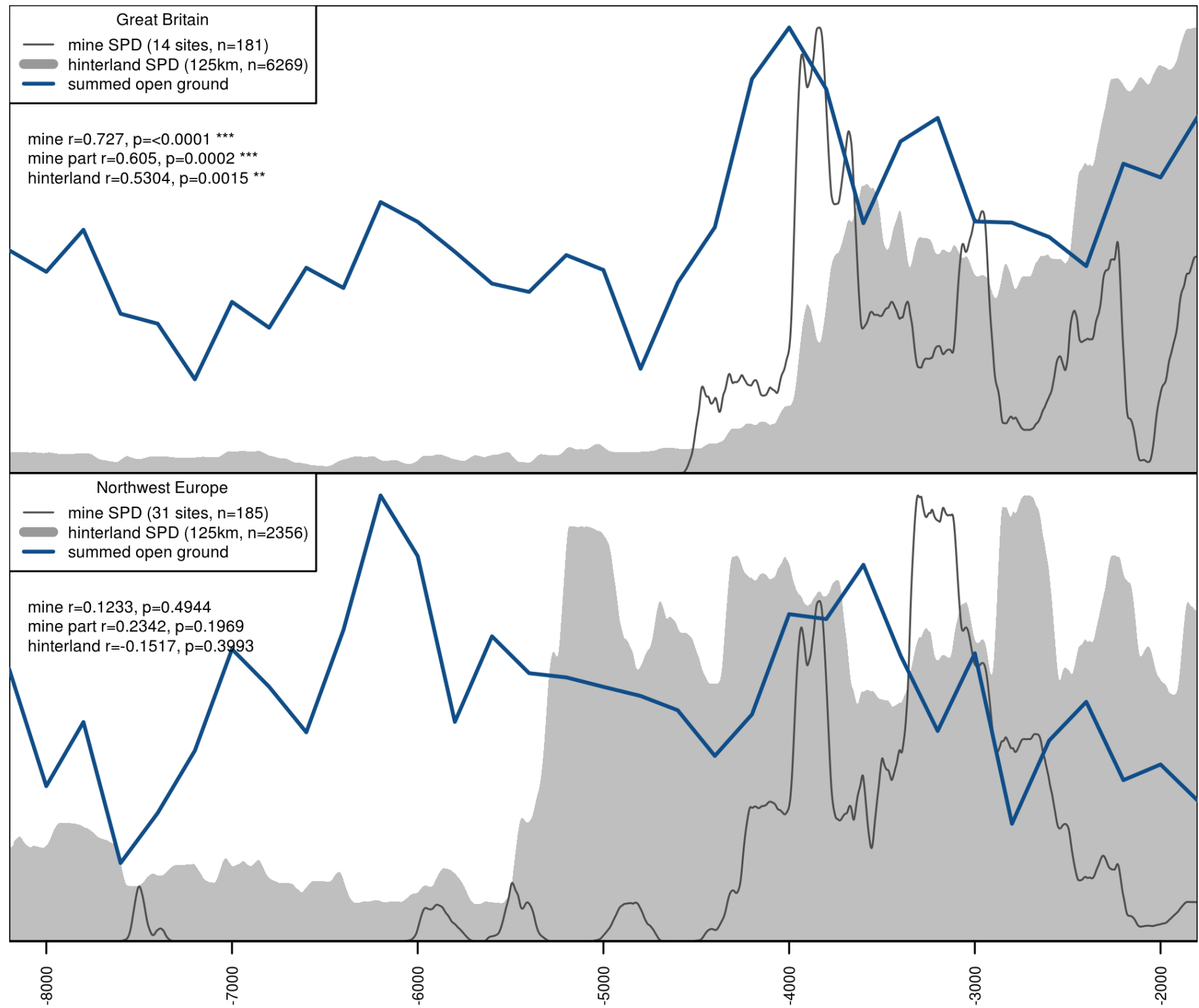

Fig 5 Comparison of REVEALS human impact on land cover (percentage of open ground) summed from all pollen sites within $125 \mathrm{~km}$ of all mines, with the SPDs of hinterland population and mining activity for a) Britain b) NW Europe. The correlations between the percentage open land cover estimate and the SPDs of hinterland population and mining activity and their probabilities under the assumption of no relationship are also shown, together with the values for the partial correlation between open ground cover and mining activity when population is controlled. 


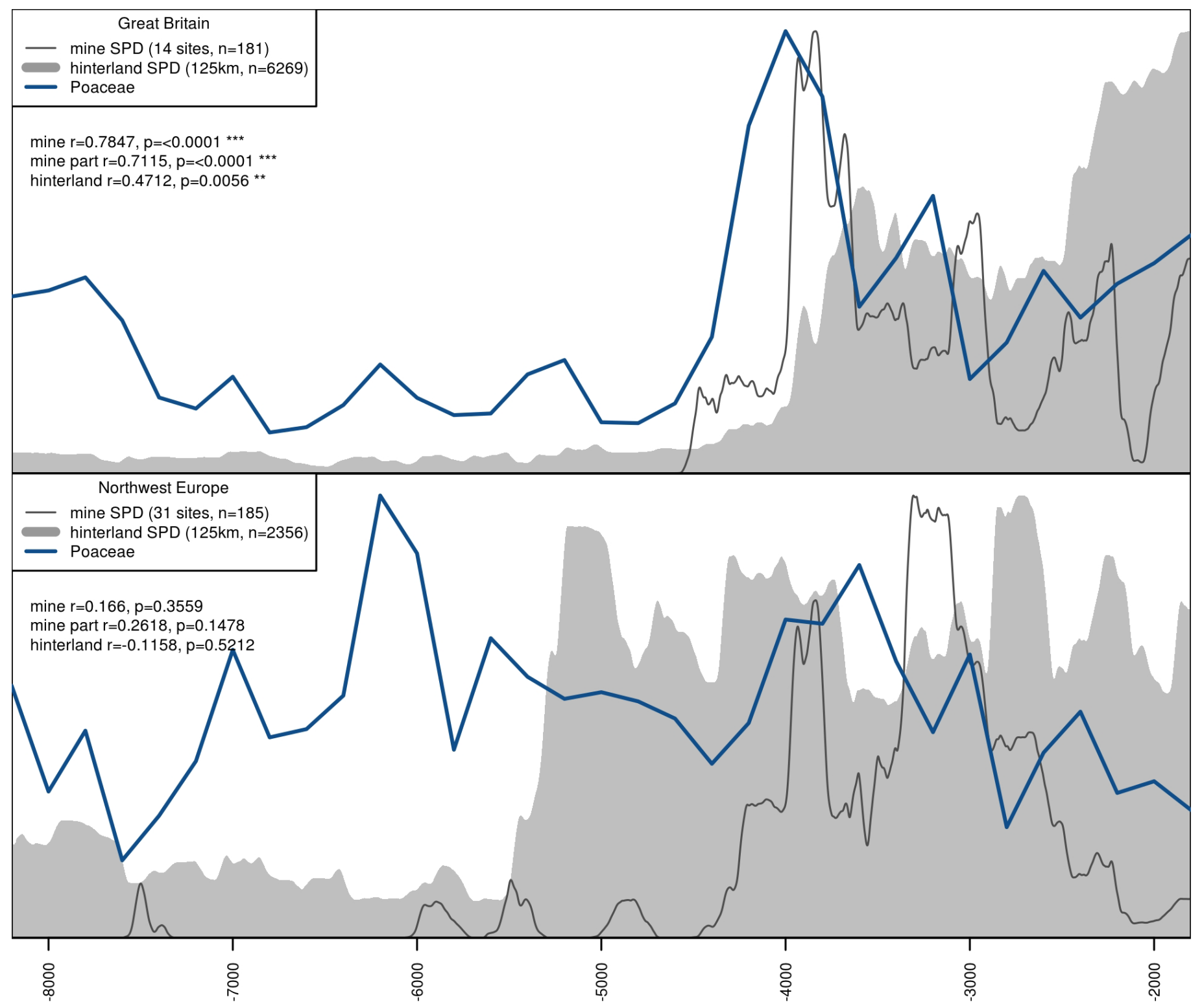

Fig 6 Comparison of REVEALS Poaceae (percentage of Poaceae grass cover) summed from all pollen sites within $125 \mathrm{~km}$ of all mines, with the SPDs of hinterland population and mining activity for a) Britain b) NW Europe. The correlations between the percentage Poaceae cover estimate and the SPDs of hinterland population and mining activity and their probabilities under the assumption of no relationship are also shown, together with the values for the partial correlation between Poaceae ground cover and mining activity when population is controlled. 


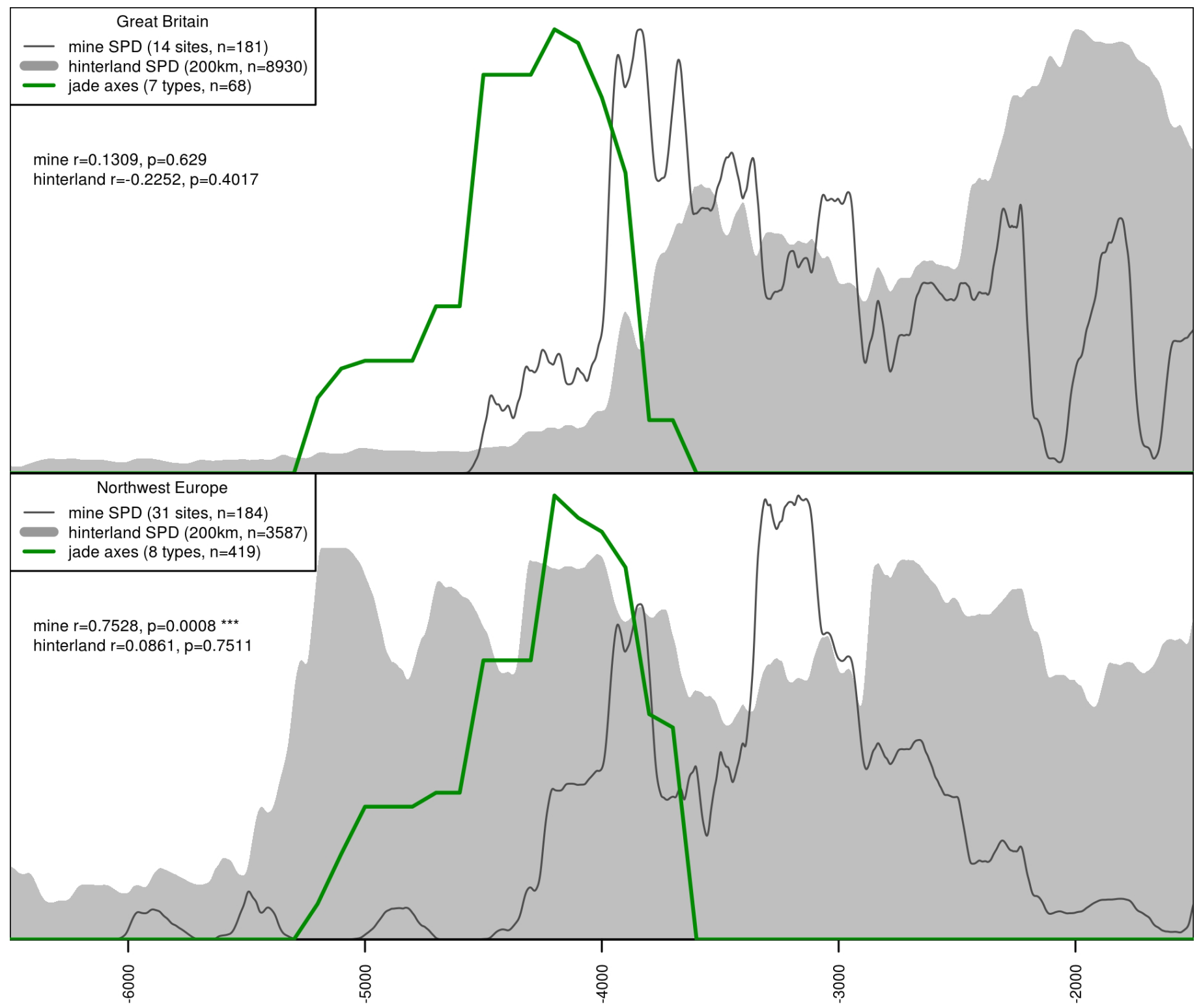

Fig 7 Comparison of the aoristic distribution of large jade axes within a $200 \mathrm{~km}$ hinterland of all mines, with the SPDs of hinterland population and mining for a) Britain b) NW Europe. Correlations between the aoristic distribution of jade axe frequency through time and the SPDs of mining activity and hinterland population are also shown. 


\section{Radiocarbon date references}

Radiocarbon dates from archaeological sites were compiled from existing online databases and electronic and print journals and books as listed below. A spreadsheet of dates used is available on request.

Allen, M.J., Smith, M., Jay, M., Montgomery, J., Bronk Ramsey, C., Cook, G. and Marshall, P. 2016. Wor Barrow, Cranborne Chase, Dorset. Chronological modelling. Historic England Research Report Series 92016.

Ambers, J. 1998. Dating Grimes Graves. Radiocarbon 40(2): 591-600.

Andrews, P., Booth, P., Fitzpatrick, A.P. and Welsh, K. 2015. Digging at the Gateway: archaeological landscapes of south Thanet. The archaeology of the East Kennet Access (Phase II) Volume 1: The sites. Volume 2: The finds, environmental and dating reports. Oxford Wessex Archaeology Monograph No. 8. Archaeology Scotland. 2010. Discovery and Excavation in Scotland [data-set]. York: Archaeology Data Service [distributor] https://doi.org/10.5284/1000284

Arnoldussen, S. and Fontijn, D. 2006. Towards familiar landscapes? On the nature and origin of Middle Bronze Age landscapes in the Netherlands. Proceedings of the Prehistoric Society 72: 289-317.

BANADORA. Banque Nationale de Données Radiocarbonne pour l'Europe et le Proche Orient, Centre de Datation par le Radiocarbonne, CNRS Lyon: http://www.arar.mom.fr/banadora/

Barber, A. 2014. South Wales Gas Pipeline Project, Site 503, Land east of Vaynor Farm, Llanddowror, Carmarthenshire. Cotswold Archaeology unpublished report series.

Barclay, A. and Marshall, P. 2011. In, Fitzpatrick, A.P. and Barclay, A. (eds.) The Amesbury Archer and the Boscombe Bowmen: Bell Beaker burials on Boscombe Down, Amesbury, Wiltshire. Wessex Archaeology Report 27. Wessex Archaeology, Salisbury.

Barclay, A.J. and Stevens, C.J. 2015. In, Powell, A.B., Barclay, A.J. Mepham, L. and Stevens, C.J., Imperial College Sports Ground and RMC Land, Harlington. Wessex Archaeology Reports Voume 33.

Bayliss, A., Bronk Ramsey, C., Cook, G. and van der Plicht, J. 2007. Radiocarbon dates: from samples funded by English Heritage under the Aggregates Levy Sustainability Fund 2002-4. English Heritage, Swindon.

Bayliss, A., Bronk Ramsey, C., Cook, G., Marshall, P., McCormac, G. and van der Plicht, J. 2017. Radiocarbon dates: from samples funded by English Heritage between 1998 and 2003. English Heritage, Swindon.

Bayliss, A., Bronk Ramsey, C., Cook, G., McCormac, G. and Marshall, P. 2015. Radiocarbon dates: from samples funded by English Heritage between 1993 and 1998. Historic England, Swindon. 
Bayliss, A., Bronk Ramsey, C., Cook, G., McCormac, G., Otlet, R. and Walker, J. 2013. Radiocarbon dates: from samples funded by English Heritage between 1988 and 1993. English Heritage, Swindon.

Bayliss, A., Cook, G., Bronk Ramsey, C., van der Plicht, J. and McCormac, G. 2008. Radiocarbon dates: from samples funded by English Heritage under the Aggregates Levy Sustainability Fund 2004-7. English Heritage, Swindon.

Bayliss, A., Hedges, R., Otlet, R., Switsur, R. and Walker, J. 2012. Radiocarbon dates: from samples funded by English Heritage between 1981 and 1988. English Heritage, Swindon.

Bayliss, A., McAvoy, F. and Whittle, A. 2007. The world recreated: redating Silbury Hill in its monumental landscape. Antiquity 81: 26-53.

Bradley, R., Haselgrove, C., Vander Linden, M. and Webley, L. 2014. The later prehistory of Northwest Europe: the evidence of recent fieldwork [data-set]. York: Archaeology Data Service [distributor] https://doi.org/10.5284/1028200

Brightman, J. 2009. Archaeological excavations at Mercia Marina, Willington. Archaeological Research Services. doi:10.5284/1009349

Burrow S, Williams S. 2008. The Wales and Borders Radiocarbon Database, Amgueddfa Cymru: National Museum Wales (https://museum.wales/en/radiocarbon)

Canmore Scottish Radiocarbon Database (former lead: Patrick Ashmore, https://canmore.org.uk/project/919374)

Card, N., Mainland, I., Timpany, S., Towers, R., Batt, C., Bronk Ramsey, C., Dunbar, E., Reimer, P., Bayliss, A., Marshall, P. and Whittle, A. 2017. To cut a long story short: formal chronological modelling for the Late Neolithic site of Ness of Brodgar, Orkney. European Journal of Archaeology 21(2): 217-263.

CBA. 2012. Archaeological Site Index to Radiocarbon Dates from Great Britain and Ireland Council for British Archaeology Radiocarbon Index (lead: Mike Heyworth, archaeologydataservice.ac.uk/archives/view/c14_cba/)

Chaffey, G., Barclay, A. and Pelling, R. 2016. Horton Kingsmead Quarry Volume 1. Wessex Archaeology Reports 32.

Conneller, C., Bayliss, A., Milner, N. and Taylor, B. 2016. The resettlement of the British landscape: towards a chronology of Early Mesolithic lithic assemblage types, Internet Archaeology 42.

https://doi.org/10.11141/ia.42.12

Cooke, N. and Mudd, A. (eds.) 2014. A46 Nottinghamshire. The archaeology of the Newark to Widmerpool improvement scheme, 2009. Cottswold/Wessex Archaeology. 
Cooke, N., Brown, F. and Phillpotts, C. 2008. From hunter gatherer to huntsmen: a history of the Stansted landscape. Framework Archaeology, Salisbury.

Crellin, R.J. 2014. Changing times: the emergence of a Bronze Age on the Isle of Man. Unpublished PhD Thesis, University of Newcastle upon Tyne.

Crockett, A.D., Allen, M.J. and Scaife, R.G. 2002. A Neolithic trackway within peat deposits at Silvertown, London. Proceedings of the Prehistoric Society 68: 185-213.

Crombé, P., Verhegge, J., Deforce, K., Meylemans, E. and Robinson, E. 2015. Wetland landscape dynamics, Swifterbant land use systems, and the Mesolithic-Neolithic transition in the southern North Sea basin. Quaternary International 378: 119-133.

Database ORAU, https://c14.arch.ox.ac.uk/database/;

de Carle, D.E. 2014. Changing plant subsistence in Prehistoric Southwest Britain: archaeobotanical and anthracological evidence from the South Cadbury Environs Project. PhD Thesis, University of Sheffield.

Denaire, A., Lefranc, P., Wahl, J., Bronk Ramsey, C., Dunbar, E., Goslar, T., Bayliss, A., Beavan, N., Bickle, P. and Whittle, A. 2017. The cultural project: formal chronological modelling of the early and middle Neolithic sequences in Lower Alsace. Journal of Archaeological Method and Theory 24(4): 1072-1149.

Dubouloz, J. 2003. Datation absolue du premier Néolithique du Bassin parisien : complément et relecture des données RRBP et VSG. Bulletin de la Société préhistorique française 100(4): 671-689.

Duffy, P.R.J. 2007. Excavations at Dunure Road, Ayrshire: a Bronz Age cist cemetery and standing stone. Proceedings of the Society of Antiquaries of Scotland 137: 69-116.

Edinborough, K., S.Shennan, A. Teather, J. Baczkowski, A. Bevan, R. Bradley, G. Cook, T. Kerig, M. Parker Pearson, A. Pope, P. Schauer, under review. New radiocarbon dates show Early Neolithic date of flintmining and stone quarrying in Britain.

Fahlke, J.M. 2009. Der Austausch der terrestrischen Säugetierfauna an der Pleistozän/Holozän-Grenze in Mitteleuropa. PhD Thesis, Universität Bonn.

FEPRE. The Formation of Europe: Prehistoric Population Dynamics and the Roots of Socio-Cultural Diversity (http://fepre.mas.ncl.ac.uk)

Foreman, S. 2018. Channel Tunnel Rail Link Section 1 [data-set]. York: Archaeology Data Service [distributor] https://doi.org/10.5284/1000230

Gibson, A. 2010. Dating Balbirnie: recent radiocarbon dates from the stone circle and cairn at Balbirnie, Fife, and a review of its place in the overall Balfarg/Balbirnie site sequence. Proceedings of the Society of Antiquaries of Scotland 140: 51-77. 
Gibson, A. and Bayliss, A. 2009. Recent research at Duggleby Howe, North Yorkshire. The Archaeological Journal 166: 39-78.

Gibson, A., Bayliss, A., Heard, H., Mainland, I., Ogden, A.R., Bronk Ramsey, C., Cook, G., van der Plicht, J. and Marshall, P. 2010. Recent work on the Neolithic round barrows of the Upper Great Wold Valley, Yorkshire. In, Leary, J., Darvill, T. and Field, D. (eds.), Round mounds and monumentality in the British Neolithic and beyond. Neolithic Studies Group Seminar Papers 10. Oxbow Books, Oxford. pp. 72-107.

Grant, M.J., Norcott, D. and Stevens, C.J. 2012. By river, fields and factories. Archaeological and cultural heritage investigations on the site of the London 2012 Olympic and Paralympic games palaeoenvironmental (Section 1). Wessex Archaeology unpublished report series. doi:10.5284/1033827 Griffiths, S. 2011. Chronological modelling of the mesolithic-neolithic trasition in the midlands and north of England. Unpublished PhD Thesis, Cardiff University.

Griffiths, S. 2016. In, Richards, C. and Jones, R. (eds.) The development of Neolithic house societies in Orkney: investigations in the Bay of Firth, Mainland, Orkney (1994-2014). Windgather Press, Oxford. Hart, D. 2010. A post-excavation assessment and updated project design for excavations at the Brighton and Hove Wastewater Treatment Works, Lower Hoddern Farm, Peacehaven, East Sussex (Stage 3). Archaeology South East, ASE Report no. 2010098. doi:10.5284/1027244

Hart, D. 2015. Early Neolithic trackways in the Thames floodplain at Belmarsh, London Borough of Greenwich. Proceedings of the Prehistoric Society 81: 215-237.

IRPA/KIK. Royal Institute for Cultural Heritage web based Radiocarbon database. Van Strydonck, M. and De Roock, E., 2011. Royal Institute for Cultural Heritage web-based radiocarbon database. Radiocarbon, 53(2), pp.367-370. http://c14.kikirpa.be/

Johnson, B. and Tinsley, A. 2010. Archaeological excavations at Bolton Hill Quarry, Pembrokeshire. Archaeological Research Services Report No. 2010/50.

Jones, A.M. 2006. Monuments and memories set in stone: a Cornish Bronze Age ceremonial complex in its landscape (on Stannon Down). Proceedings of the Prehistoric Society 72: 341-365.

Jones, A.M. and Quinnell, H. 2013. Daggers in the west: Early Bronze Age daggers and knives in the southwest peninsula. Proceedings of the Prehistoric Society 79: 165-191.

Jordan, D., Haddon-Reece, D. and Bayliss, A. 1994. Radiocarbon dates: from samples funded by English Heritage and dated before 1981. English Heritage, London.

Kenney, J. 2014. Gas Pipeline Replacement: Pwllheli to Blaenau Ffestiniog. Report on archaeological mitigation. Volume 1. Unpublished Report. Gwyneddd Archaeological Trust 1136. 
Knight, M. and Brudenell, M. (in prep.) Pattern and Process. Landscape Prehistories from the Whittlesey Brick Pits. The King's Dyke and Bradley Fen Excavations 1998 - 2004. CAU Flag Fen Basin Depth and Time Series Volume 1.

Lanting, J.N. and van der Plicht, J. 1999/2000. De 14C-chronologie van de Nederlandse pre- en protohistorie, III: Neolithicum. Palaeohistoria 41/42: 1-110.

Loader, R.D. 2006. Isle of Wight coastal assessment enhancement. Project proposal (Project 4842), MAP2 project proposal prepared by the Isle of Wight County Archaeology and Historic Environment Service.

Luke, M. 2016. Close to the Loop: landscape and settlement evolution beside the Biddenham Loop, west of Bedford. East Anglian Archaeology 156.

Manning K, Colledge S, Crema E, Shennan S, Timpson A. 2016. The Cultural Evolution of Neolithic Europe. EUROEVOL Dataset 1: Sites, Phases and Radiocarbon Data, Journal of Open Archaeology Data 5, p e2 (lead: Stephen Shennan, doi.org/10.5334/joad.40)

Martineau, R. (ed.), 2018. Les occupations néolithiques des marais de Saint-Gond. Volume 2. Vert-laGravelle (Vert-Toulon, Marne) «La Crayère ». Minière de silex et nécropole d’hypogées. Unpublished report.

Masefield, R. (ed.), Chapman, A., Ellis, P., Hart, J., King, R. and Mudd, A. 2015. Origins, development and abandonment of an Iron Age village: further archaeological investigations for the Daventry International Rail Freight Terminal, Crick \& Kilsby, Northamptonshire 1993-2013. Archaeopress, Oxford.

McKinley, J.I., Leivers, M., Schuster, J., Marshall, P., Barclay, A. J. and Stoodley, N. 2015. Cliffs End Farm, Isle of Thanet, Kent: a mortuary and ritual site of the Bronze Age, Iron Age and Anglo-Saxon period with evidence of long-distance maritime mobility. Oxbow Books, Oxford.

Mudd, A., Brett, M., Anderson-Whymark, H., Black, S., Cobain, S., Geber, J., Healy, F., Marini, N., McSloy, E.R., Morris, E.L., Price, K.M., Warman, S., Warren, G., Watson, N., Wilkinson, K. and Young, T.P. 2012. A Neolithic and Bronze Age monument complex and its early Medieval reuse: excavations at Netherfield Farm, South Petherton, Somerset, 2006. Archaeological Journal 169(1): 3-86.

Noble, G. and Brophy, K. 2011. Ritual and remembrance at a prehistoric ceremonial complex in central Scotland: excavations at Forteviot, Perth and Kinross. Antiquity 85: 787-804.

Parker Pearson, M., Chamberlain, A., Jay, M., Richards, M. and Evans, J. (eds.) 2018. The Beaker People: isotopes, mobility and diet in prehistoric Britain. Prehistoric Society Research Paper 7. Oxbow Books, Oxford.

Passmore, D.G. and Waddington, C. 2012. Archaeology and environment in Northumberland. Oxbow, Oxford. 
Paulsson, B.S. 2017. Time and Stone: the emergence and development of megaliths and megalithic societies in Europe. Archaeopress, Oxford.

Paulsson, B.S., Andersson, M., Artursson, M. and Brink, K. 2017. A highly precise chronology for the process of Neolithization in Southern Scandinavia: the ESS Project in Lund, Sweden. Radiocarbon 59(2): 583-593.

Pickstone, A. and Mortimer, R. 2011. The archaeology of Brigg's Farm, Prior's Fen, Thorney, Peterborough. Project Report (unpublished). Oxford Archaeology.

Platell, A. 2006. Post-excavation analysis report, Marne Barracks, N Yorkshire. Archaeological Services University of Durham unpublished report series. doi:10.5284/1025423

Radiocarbon Database CALPAL lead: Bernhard Weninger, including with CalPal software, monreposrgzm.de/forschung/ausstattung.html\#calpal

RADON - Radiocarbon dates online. 2014. Central European and Scandinavian database of 14C dates for the Neolithic and Early Bronze Age (lead: Martin Hinz, radon.ufg.uni-kiel.de/)

Richards, C., Jones, A.M., MacSween, A., Sheridan, A., Dunbar, E., Reimer, P., Baylis, A., Griffiths, S. and Whittle, A. 2016. Settlement, duration and materiality: formal chronological models for the development of Barnhouse, a Grooved Ware settlement in Orkney. Proceeding of the Prehistoric Society 82: 193-225.

Rivollat, M., Mendisco, F., Pemonge, M.-H., Safi, A., Saint-Marc, D., Brémond, A., Couture-Veschambre, C., Rottier, S. and Deguilloux, M.-F. 2015. When the waves of European Neolithization met: first paleogenetic evidence from early farmers in the Southern Paris Basin. PLoS ONE 10(4): e0125521. doi:10.1371/journal.pone.0125521

Robertson, D. 2016. A second timber circle, trackways and coppicing at Holm-next-the-Sea beach, Norfolk: use of salt- and freshwater marshes in the Bronze Age. Proceedings of the Prehistoric Society 82: 227-258. Robinson, E., Van Strydonck, M., Gelorini, V. and Crombé, P. 2013. Radiocarbon chronology and the correlation of hunter-gatherer sociocultural change with abrupt palaeoclimatic change: the Middle Mesolithic in the Rhine-Meuse-Scheldt area of northwest Europe. Journal of Archaeological Science 40: 755-763.

Salanova, L., Brunet, P., Cottiaux, R., Hamon, T., Langry-François, F., Martineau, R., Polloni, A., Renard, C. and Sohn, M. 2011. Du Néolithique récent à l'âge du Bronze dans le centre nord de la France: les étapes de l'évolution chrono-culturelle. Review Archéologique de Picardie. Numéro spécial 28: 77-102.

Smith, A., Powell, K. and Laws, G. 2010. Evolution of a farming community in the Upper Thames Valley: excavation of a prehistoric Roman and post-Roman landscape at Cotswold Community, Gloucestershire and Wiltshire. Oxford Archaeology, Oxford. 
Sørensen, L. 2014. From hunter to farmer in northern Europe: migration and adaptation during the Neolithic and Bronze Age. Acta Archaeologica 85.1. Wiley, Oxford.

Speed, G. 2010. Mitchell Laithes Farm, Ossett, West Yorkshire. Excavation Report. Northern Archaeological Associates. doi:10.5284/1029397

Stevens, C.J. and Fuller, D.Q 2012. Did Neolithic farming fail? The case for a Bronze Age agricultural revolution in the British Isles. Antiquity 86: 707-722.

Thompson, S. and Powell, A.B. 2018. Along prehistoric lines: Neolithic, Iron Age and Romano-British activity at the former MOD Headquarters, Durrington, Wiltshire. Wessex Archaeology, Salisbury.

Timberlake, S. 2014. Prehistoric copper extraction in Britain: Ecton Hill, Staffordshire. Proceedings of the Prehistoric Society 80: 159-206.

Tixier, B. 2014. Loisy-sur-Marne (51), "ZAC de la Haute Voie - Zone D1", Rapport final d'opération archéologique, Éveha - Études et valorisations archéologiques (Limoges, F), Service régional de l'Archéologie de Champagne-Ardenne

Toussaint, M., Pirson, S., Frébutte, C. and Valotteau, F. 2005. Critères d'identification des menhirs dans la Préhistoire belgo-luxembourgeoise. Bulletin de la Société préhistorique française 102(3): 597-611.

van der Sluis, B. 2010. Archeologisch onderzoek langs de rijksweg N11 (Spookverlaat) ten behoeve van de aanleg van het windturbinepark Rijnwoude te Hazerswoude-Rijndijk (gem. Rijnwoude, prov. Zuid-Holland). ArcheoMedia Rapport AO6-286-R en AO6-359-R.

Vander Linden, M. 2006. Le phénomène campaniforme dans l'Europe du 3ème millénaire avant notre ère: synthèse et nouvelles perspectives. BAR International Series; 1470. Archaeopress, Oxford.

Whittle, A.W.R., Healy, F. and Bayliss, A. 2011. Gathering time: dating the early Neolithic enclosures of southern Britain and Ireland. Oxbow, Oxford.

Willis, C., Marshall, P., McKinley, J., Pitts, M., Pollard, J., Richards, C., Richards, J., Thomas, J., Waldron, T., Welham, K. and Parker Pearson, M. 2016. The dead of Stonehenge. Antiquity 90: 337-356. 